\title{
EFFECTS OF QUERCETIN ON EXERCISE POTENTIAL AND EXERCISE- INDUCED CYTOKINES IN THE HORSE
}

\author{
by \\ JAMES BALDASSARI \\ A Thesis submitted to the \\ Graduate School-New Brunswick \\ Rutgers, The State University of New Jersey \\ in partial fulfillment of the requirements \\ for the degree of \\ Masters of Science
}

Graduate Program in Endocrinology and Animal Biosciences

written under the direction of

Dr. Kenneth McKeever

and approved by

New Brunswick, New Jersey

January, 2011 


\begin{abstract}
OF THE THESIS By James Baldassari

Thesis Director:

Dr. Kenneth McKeever
\end{abstract}

Effects of quercetin on exercise potential and exercise-induced cytokines in the horse

Inflammation, the common physiological response to a wide variety of injuries and irritations, has been studied in one form or another for literally thousands of years. Most non-steroidal anti-inflammatory drugs (NSAIDS) work by inhibiting the production of prostaglandins (PG) via inactivation or modification of the cyclooxygenase (COX) enzyme. Unfortunately disruption of the COX pathway can have unintended consequences, such as an increase in tumor necrosis factor alpha $(\mathrm{TNF}-\alpha)$ levels. In vitro studies consistently show reductions in inflammatory cytokines, including TNF- $\alpha$ and interkeukin-1 (IL-1), in cultures of immune cells after treatment with quercetin. Studies run in vivo have been less decisive. Hence, our goal in this experiment was to test the hypothesis that quercetin, in sufficient dosage, will increase athletic performance in the horse by decreasing exercise-induced inflammation via inhibition of the production of inflammatory cytokines. Six healthy, unfit Standardbred mares ( $\sim 500 \mathrm{~kg}$, age 4-5 years) were assigned to one of two groups in a crossover fashion. The horses were dosed via a nasogastric tube BID (8 am and $8 \mathrm{pm}$ ) with $6 \mathrm{~g}$ of quercetin in tap water for 3.5 days. Two hours after the seventh and final dose, a graded exercise test (GXT) was run. During the test the treadmill remained at a fixed $6 \%$ grade. At $\mathrm{T}=0$ the treadmill was started at a speed 
of $4 \mathrm{~m} / \mathrm{sec}$. Each following minute the treadmill speed was increased by $1 \mathrm{~m} / \mathrm{sec}$, up to a maximum speed of $11 \mathrm{~m} / \mathrm{sec}$. Blood and muscle samples were collected to measure markers of inflammation. There was a small but significant increase in run time when the horses were dosed with quercetin, and recovery time was shortened significantly when compared to water-treated trials. There were exercise-induced increases in plasma TNF- $\alpha$, IL-1, interferon- $\gamma$, granzyme-B (GrB), hematocrit, total protein, glucose, and lactate, but only with GrB was there a significant drug effect in the quercetin group. Intramuscular levels of IL-1 and GrB also increased significantly with exercise, but there was no effect from quercetin treatment. This study provides compelling evidence that quercetin could be useful in enhancing exercise performance, although the mechanism for this enhancement is unclear. While this study alone is not sufficient to recommend quercetin for mainstream usage, it adds to a growing body of literature supporting the drug's effectiveness. 


\section{ACKNOWLEDGEMENTS}

I am deeply indebted to my thesis committee: Drs. McKeever, Malinowski, and Horohov. Dr. McKeever in particular has been knowledgeable and patient in his guidance. I would also like to thanks Dr. Michniak and the New Jersey Center for Biomaterials for their guidance and use of their equipment, without which the HPLC portions of the PK study would not have been possible. Thank you as well to Dr. Horohov at the University of Kentucky for running PCR on our blood and muscle samples. Special thanks must be given to the undergraduate students who assisted during the dosing and exercise portions of the study, many of who went above and beyond merely fulfilling their duties and took an active interest in the experiment. Lastly, I thank Don Thompson, Ken Harries, Eva Smith, Catherine Abbadie, Amy Ritter, Ester Carballo-Jane, Gina Chevalier, and the Merck company as a whole for providing the financial support and flexibility that made this graduate degree possible. 


\section{TABLE OF CONTENTS}

ABSTRACT

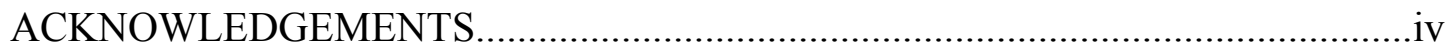

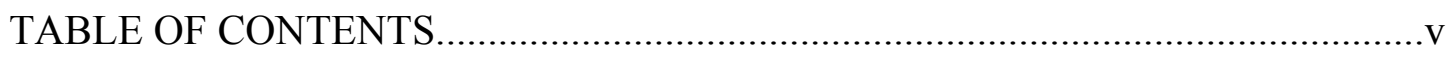

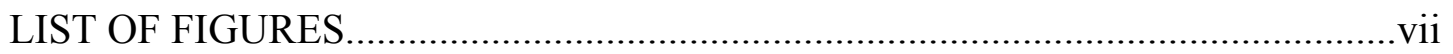

\section{CHAPTER I: REVIEW OF LITERATURE}

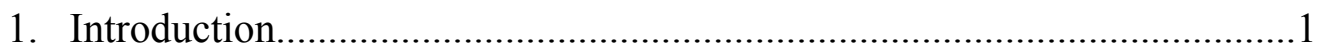

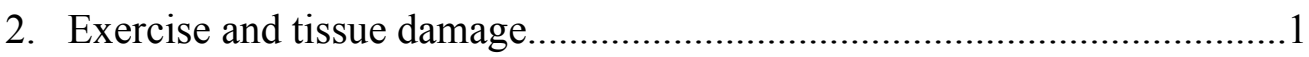

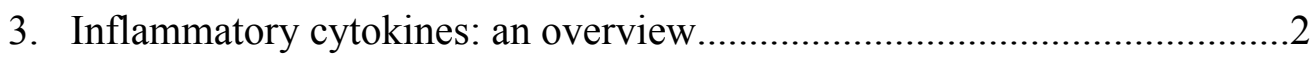

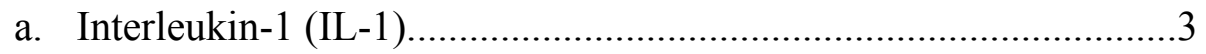

b. Tumor necrosis factor- $\alpha($ TNF- $\alpha) \ldots \ldots \ldots \ldots \ldots \ldots \ldots \ldots \ldots \ldots \ldots \ldots \ldots \ldots \ldots \ldots \ldots . . .4$

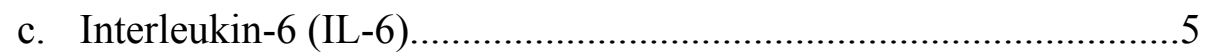

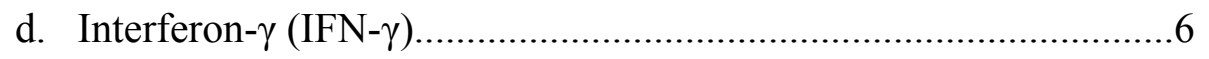

e. Granzyme A \& granzyme B (GrA \& GrB) ...................................

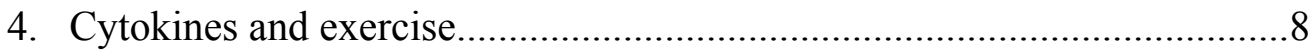

5. The horse as a human analog in human trials...........................................

6. Quercetin

a. Studies on anti-inflammatory effects..............................................10

b. Methods of action..........................................................................

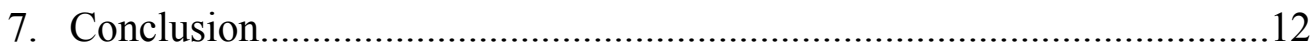

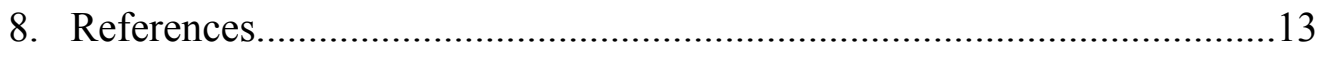




\section{CHAPTER II: EFFECTS OF QUERCETIN ON EXERCISE POTENTIAL AND EXERCISE-INDUCED CYTOKINES IN THE HORSE}

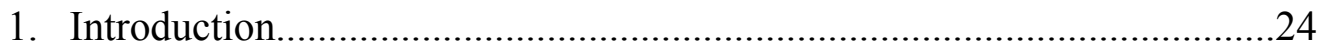

2. Materials and methods

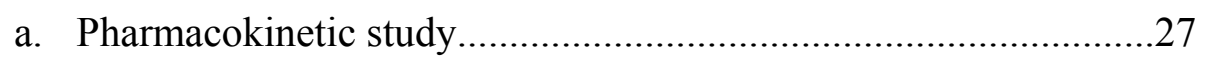

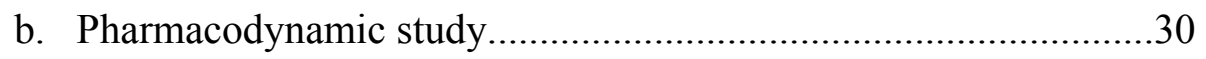

3. Results

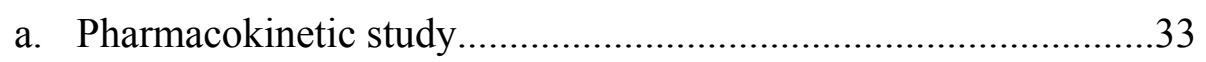

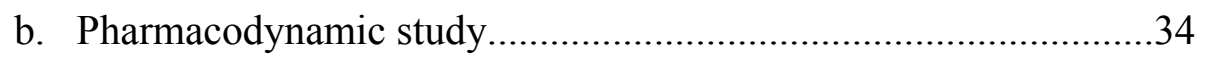

4. Discussion

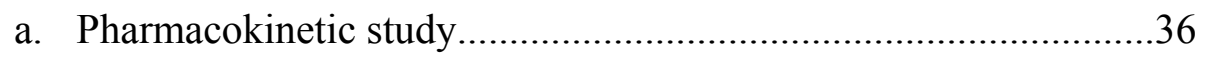

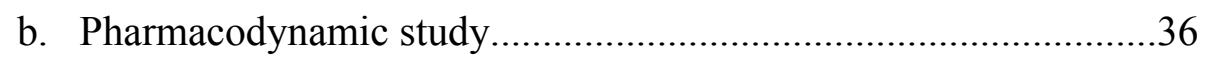

\section{CHAPTER III: CONCLUSION}

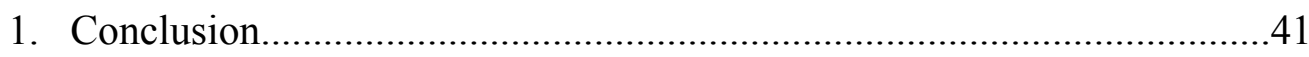

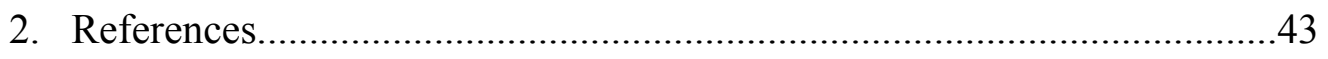

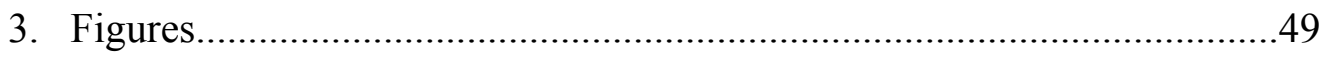




\section{LIST OF FIGURES}

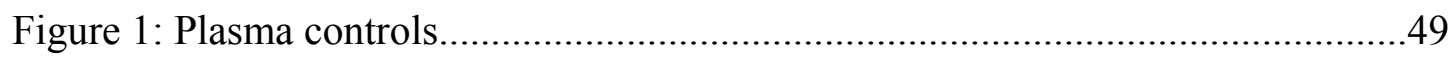

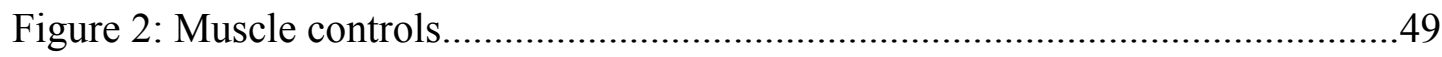

Figure 3: Quercetin PK plasma concentration.......................................................50

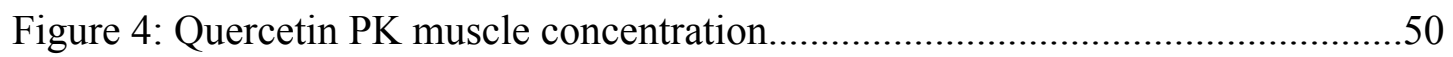

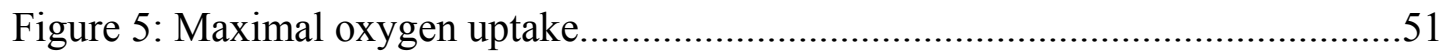

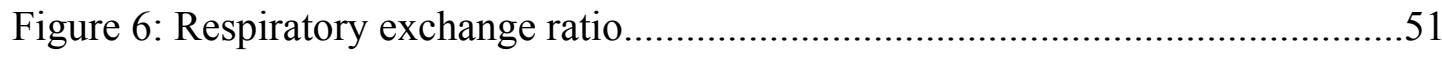

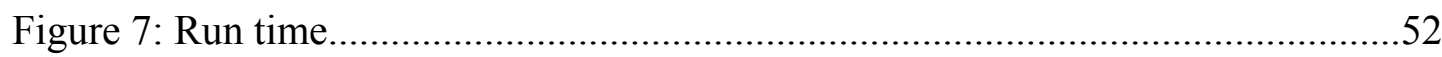

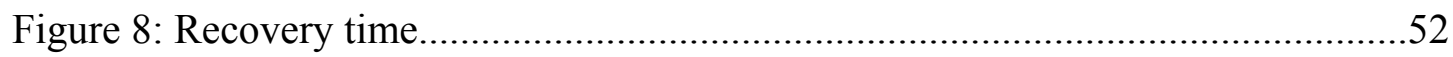

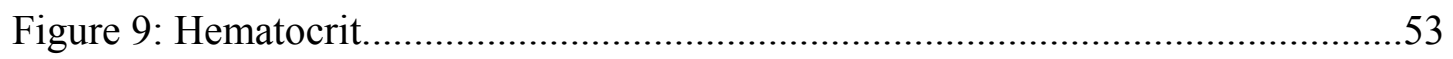

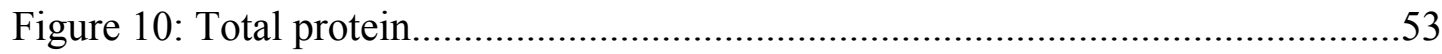

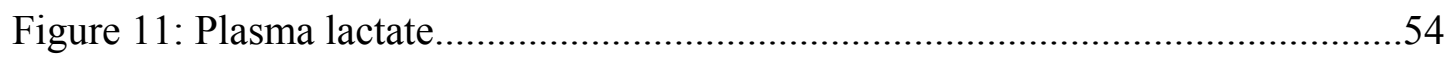

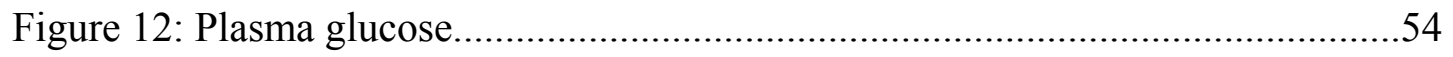

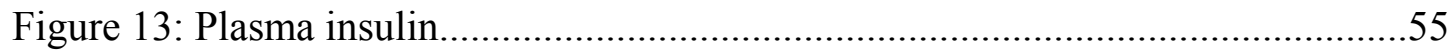

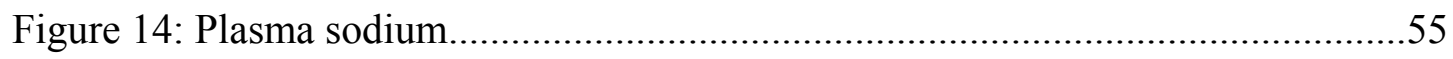

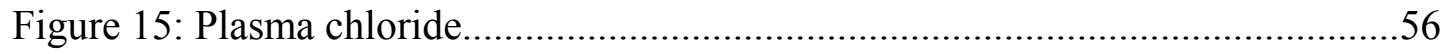

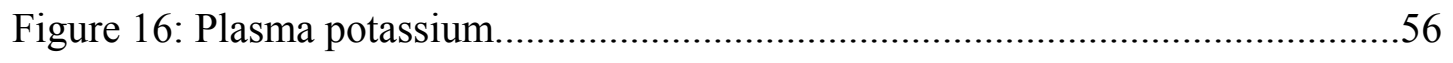

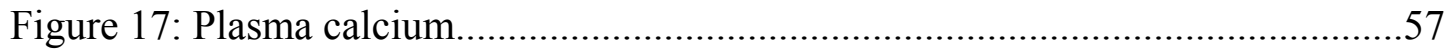

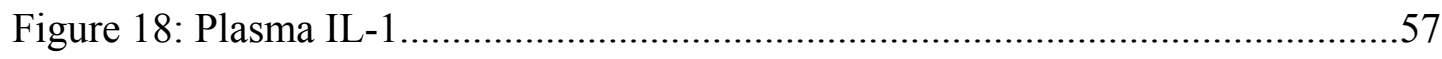

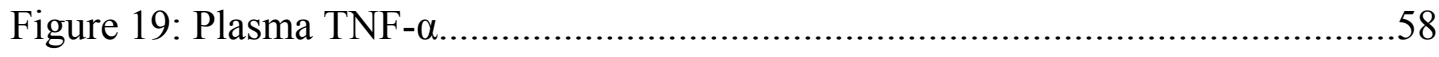

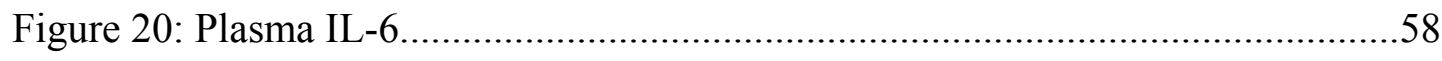

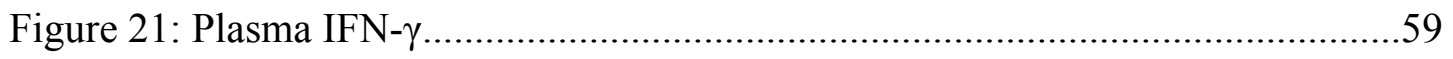

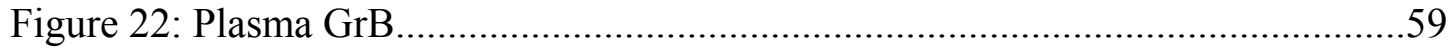




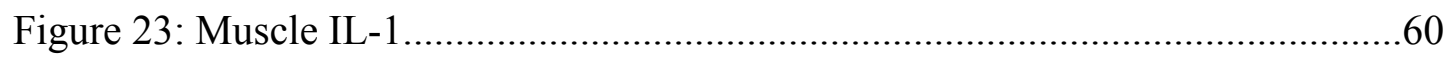

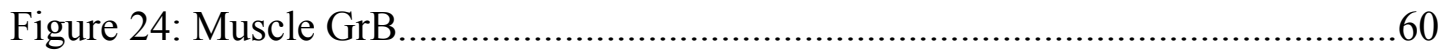




\section{Chapter one: Review of Literature \\ Introduction}

An abundance of evidence exists pointing to a link between exercise, muscle damage, immune response, and inflammation. This link is established by cytokines: cellular proteins involved in mediating immune response and inflammation in response to infection or trauma. Cytokine effects are often both redundant and synergistic, so attempting to pharmacologically alter or inhibit their activity can be difficult and have unintended side effects. Quercetin, a type of plant-derived antioxidant known as a flavonoid, has shown promise both in vitro and in vivo in treating immune systeminduced inflammation and associated increases in cytokine concentration. As strenuous exercise is often limited by soreness and inflammation, the purpose of this study was to test the hypothesis that quercetin can increase athletic performance and lower cytokine markers of inflammation.

\section{Exercise and tissue damage}

Exercise-induced muscle soreness is typically described as either acute (during or immediately following exercise), or delayed onset muscle soreness (DOMS), which typically presents itself 12-48 hours after exercise. DOMS in humans may result from connective tissue and muscle microlesions, muscle spasms, acidosis, and/or inflammation (Coudreuse et al., 2004).

An elevated level of lactate in response to exercise has been described in the horse (Snow and Valberg, 1994), and increased lactic acid levels are associated with muscle fatigue, soreness, cramping, oxygen debt, and anaerobic threshold in humans(Brooks, 1988). Levels of the pro-inflammatory, pro-algesic compound prostaglandin $\mathrm{E}_{2}\left(\mathrm{PGE}_{2}\right)$ 
increase in response to exercise, an effect that can be negated in humans by the analgesics ibuprofen and acetaminophen (Trappe et al., 1987).

Increases in creatine kinase $(\mathrm{CK})$ concentrations are commonly associated with muscle damage in humans (Bruunsgaard et al., 1997; Ostrowski et al., 1998b, Toft et al., 2002), although this increase may not be linked quantitatively or even qualitatively with the severity of the damage (Evans and Cannon, 1991). In contrast, other human studies have shown significantly higher CK levels following eccentric (lengthening) muscle contractions when compared to concentric (shortening) contractions (Croisier et al., 1996). Ultrastructural muscle damage, which occurs when muscle cells containing contractile proteins suffer microscopic tears, has been shown to follow eccentric exercise (Evans and Cannon, 1991). It should be noted that this is the same study which did not find a link between CK levels and degree of muscle damage.

\section{Inflammatory cytokines: an overview}

The term cytokine refers to a variety of pleiotropic cellular proteins involved in mediating both pro- and anti-inflammatory effects. While most cytokines function in an autocrine or paracrine manner (Kaplan, 1996), several may also have systemic effects. Cytokines behaving in an endocrine manner, such as interleukin-1ß (IL-1ß), interleukin-6 (IL-6), and tumor necrosis factor- $\alpha$ (TNF- $\alpha)$, can have far-reaching effects, such as inducing generalized septic shock syndrome in species ranging from mice to humans (Beutler and Cerami, 1987; Akira et al, 1993; Dinarello, 1996). IL-1ß and TNF- $\alpha$ can also have biologic activity when expressed on the cell surface in membrane-bound form (Kaplanski et al., 1994; Schmid et al. 1995). 
Cytokines often function in a cascade, their presence inducing activation of other cytokines. A well described model involves lipopolysaccharide (LPS)-induced sepsis in animals (Beutler and Cerami, 1987). LPS induces production of TNF- $\alpha$, which in turn triggers increased levels of IL- $1 \beta$, followed by a rise in IL- 6 concentration. If TNF- $\alpha$ is dosed directly without introduction of LPS, the cascade continues normally (Beutler and Cerami, 1987).

Regulation of inflammatory cytokines typically involves two processes. Many cytokines, including IL- $1 \beta$ and TNF- $\alpha$, are held in a biologically inert form until activated. For instance, the protocytokine precursor to IL-1ß remains in the cytosol, inactive, until it is cleaved by the protease IL-1-converting enzyme (Hazuda et al., 1990; Cerretti et al., 1992; Thornberry et al., 1992). Alternatively, the cytokine's receptor may be used to control activity. There are two subtypes of IL-1 receptor (IL-1R), one that is biologically active (type I) and one that is not (type II). The type II IL-1R binds IL-1 without initiating a response, effectively limiting IL-1 bioactivity (Colotta et al., 1994). In addition an inactive form of IL-1ß, known as the IL-1 receptor antagonist (IL-Ra), can bind to the IL-R, limiting receptor availability for IL-1ß (Dinarello, 1996). Interleukin-1 (IL-1)

IL-1 is a pleiotropic cytokine that acts on leukocytes, endothelial cells, hepatocytes, myocytes, adipose tissue, and certain neurons (Dinarello, 1996). There are two active forms of IL-1, IL-1 $\alpha$ and IL-1 1 , and typically their biological activities are indistinguishable. The primary difference is that while IL-1ß typically acts in a paracrine or endocrine fashion, IL-1 $\alpha$ is membrane-bound and rarely found in circulation except 
after severe disease, when it may have been released from dying cells (Watanabe and Kobayashi, 1994). The third IL-1 isoform, IL-1Ra, has been previously discussed.

When IL-1ß binds to a type I IL-R, several biochemical events are induced (Kuno and Matsushima, 1994; O'Neill, 1995). One of the most notable is the phosphorylation of phospholipase $\mathrm{A}_{2}\left(\mathrm{PLA}_{2}\right)$ activating protein, which leads to a rapid release of arachidonic acid (Gronish et al., 1994). Arachidonic acid is a fatty acid and a key inflammatory intermediate. The enzymes cyclooxygenase (COX) and peroxidase are involved in transforming arachidonic acid into $\mathrm{PGE}_{2}$.

Tumor necrosis factor- $\alpha(T N F-\alpha)$

TNF- $\alpha$ is an inflammatory cytokine produced by many cell types within the body, though primarily by macrophages. There is a fair amount of redundancy between the effects of TNF- $\alpha$ and IL-1, including adhesion molecule upregulation and accumulation of leukocytes in sites of inflammation. Like IL-1, TNF- $\alpha$ initiates several inflammatory pathways, including the formation of the inflammatory lipid $\mathrm{PGE}_{2}$ via the COX enzyme. The rising $\mathrm{PGE}_{2}$ levels inhibit further TNF- $\alpha$ release in a negative feedback loop. In the case of NSAID antagonism of the COX enzyme, the inhibition of $\mathrm{PGE}_{2}$ formation precludes the negative feedback loop from occurring. Thus TNF- $\alpha$ levels rise (Endres et al., 1996; Slomiany et al., 1997; Bertrand et al., 1998), and the other inflammatory pathways triggered by the cytokine, including nuclear factor kappa-light-chain-enhancer of activated B cells (NF- $\kappa \mathrm{B})$ and mitogen-activated protein kinase (MAPK), continue to function. Ironically some of the human diseases commonly treated by NSAIDS, such as rheumatoid arthritis (RA), are thought to be caused by overproduction of TNF- $\alpha$ (Camussi and Lupia, 1998). 
In addition to its pro-inflammatory effects, TNF- $\alpha$ has been linked to insulin resistance in humans (Saghizadeh et al., 1996). This study reported increased TNF- $\alpha$ concentration in muscle tissue of insulin resistant and diabetic patients. The resistance is thought to be due to inhibition of insulin receptor signaling and down-regulation of the GLU4 glucose transporter (Ferrier, 2004).

As with IL-1, there are two subtypes of TNF receptor (TNFR). Type I TNFR is responsible for the majority of TNF- $\alpha$ activity, including cytotoxicity, cytostasis, and activation of neutrophils and endothelial cells. Type II receptors are found almost exclusively on immune cells, and play a role in the proliferation of T and B cells, induction of NF- $\kappa$ B, and cytotoxicity (Hohman et al., 1990a, b). TNFR also play a role in the regulation of TNF- $\alpha$. Both receptor types can be released from the membrane, and can be found in interstitial space and in circulation. These soluble TNFR function as TNF binding proteins, effectively reducing the bioavailability of TNF- $\alpha$ (Engelmann et al., 1990).

Interleukin-6 (IL-6)

IL-6 is another pleiotropic cytokine, and is induced by infection, trauma, or immunologic challenge in nearly every human tissue and cell type (Van Snick, 1990; Hirano, 1992; Barton, 1997). While closely correlated with levels of IL-1ß and TNF- $\alpha$, IL-6 itself is not an inflammatory cytokine. Rather it is referred to as an "inflammation responsive" cytokine (Pedersen and Hoffman-Goetz, 2000), as its concentration rises quickly in response to elevated levels of IL- $\beta$, TNF- $\alpha$, and LPS (Shalaby et al., 1989). Infusion of IL-6 in humans does cause fever, but other effects of inflammatory cytokines, such as shock or capillary leakage, do not occur (Mastorakos et al., 1993). More recent 
studies have corroborated the lack of inflammatory effect (Pedersen and Hoffman-Goetz, 2000; Febbraio and Pedersen, 2002; Starkie, 2003).

A primary role of IL-6 seems to be to induce production of a broad range of acute phase proteins (APP) in hepatoma cells and hepatocytes (Kordula et al., 1991; Tilg et al., 1997). APPs include microbe-inhibiting proteins such as C-reactive protein, serum amyloid A, and fibrinogen, to name just a few. Acute inflammation results in changes in the levels of these proteins (Sehgal, 1990). While IL-1ß and TNF- $\alpha$ stimulate a limited APP subset, IL-6 is primarily responsible for the response. In fact IL-6 knock-out mice are unable to mount an APP response to injury or infection (Kopf et al., 1994).

IL-6 also serves to dampen the inflammatory effect of IL-1ß and TNF- $\alpha$. The presence of IL-6 induces corticotropin (Lenczowski et al., 1997; Raber et al., 1997; Bethin et al., 2000), which increases synthesis of glucocorticoids in the adrenal gland. Glucocorticoids, in turn, suppress the synthesis of IL-1ß and TNF- $\alpha$. This effect was demonstrated more recently by Starkie et al. (2003), who showed that IL-6 can inhibit endotoxemia-induced increases in plasma TNF- $\alpha$ concentration. Glucocorticoids also suppress further release of IL-6 (Waage et al., 1990; Amano et al., 1993). Interferon- $\gamma(I F N-\gamma)$

IFN- $\gamma$ is an inflammatory cytokine produced primarily by two main cell types: $\mathrm{T}$ cells and natural killer (NK) cells (Farrar and Schreiber, 1993; Boehm et al., 1997). It is a part of a signal-amplification system involving the cytokines TNF- $\alpha$ and IL-12 (Bancroft et al., 1991; Tripp et al., 1993). These studies demonstrated that when a macrophage is exposed to bacterial products, it will produce low levels of TNF- $\alpha$ and IL-12. These cytokines then induce IFN- $\gamma$ production from NK cells, which activates more 
macrophages in the vicinity of the infection. These newly-activated macrophages will then produce higher levels of TNF- $\alpha$ and IL-12. This positive-feedback loop facilitates early control of infection (Unanue, 1997). The process is halted by the presence of IL-10 (Tripp et al., 1993), which prevents macrophage release of TNF- $\alpha$ and IL-12. This in turn inhibits NK cell activation and IFN- $\gamma$ production.

The role of IFN- $\gamma$ in the immune response cannot be understated. In addition to activating macrophages (Nathan et al., 1983; Buchmeier and Schreiber, 1985), IFN- $\gamma$ reduces their susceptibility to microbial infection and enhances recognition of targets (Belosevic et al., 1988). Mice treated with anti-IFN- $\gamma$ antibodies (Buchmeier and Schreiber, 1985; Nacy et al., 1985; Suzuki et al., 1988; Bancroft et al., 1991) or with disrupted IFN- $\gamma$ or IFN- $\gamma$-related genes (Dalton et al., 1993; Huang et al., 1993) die when exposed to normally sub-lethal doses of various microbial pathogens. Granzyme A \& granzyme B (GrA and GrB)

Granzymes are actually serine proteases rather than cytokines, but are included here because of their relationship to inflammatory cytokines. They are released from cytotoxic lymphocytes (CL), including cytotoxic CD8 T lymphocytes (CTLs) and NK cells, in adaptive and innate immune responses, respectively (Berke, 1995a). There have been numerous studies indicating that GrA and GrB are important for the initiation of apoptosis in infected cells (Shi et al., 1992; Smyth and Trapani, 1995; Froelich et al., 1998). GrB rapidly induces apoptosis, whereas GrA acts more slowly via a different pathway (Shresta et al., 1999).

Although typically released into the intercellular space between the CL and target cell (Berke, 1995b; Kagi et al., 1996), soluble granzymes have been discovered 
systemically (Spaeny-Dekking et al., 1998). GrA and GrB levels were found to be elevated in the plasma and synovial fluid of patients with RA (Tak et a., 1999), and intravenous (IV) injection of LPS in humans induced significant increases in the concentration of both proteases (Lauw et al., 2000).

Lauw et al. (2000) also found that monoclonal antibodies (MAbs) against TNF and IL-12 greatly reduced LPS-induced secretion of GrA and GrB levels, both in vivo and in vitro. MAbs against IFN- $\gamma$ did not alter granzyme levels, indicating that the cytokine effect on the release of GrA and GrB is mediated through an IFN- $\gamma$-independent pathway. In addition to being activated by cytokines, GrA has been shown to increase release of TNF and IL-1ß in human monocytes and mouse macrophages (Metkar et al., 2008) and IL-6 and IL-8 release from human lung fibroblasts (Sower et al., 1996). The later is consistent with another study, which found increased concentration of GrB and $\mathrm{GrB}^{+}$lymphocytes in bronchoalveolar lavage (BAL) fluid in allergen-challenged atopic asthma patients (Bratke et al., 2004).

\section{Cytokines and exercise}

Myriad studies have linked exercise to a change in cytokine levels. Plasma concentrations of TNF- $\alpha$, IL-1ß, IL-1Ra, IL-6, IL-10, and IFN- $\gamma$ have been shown to increase in response to exercise in humans (Bruunsgaard et al., 1997; Ostrowski et al., 1998a; Ostrowski et al., 1998b; Ostrowski et al., 1999; Moldoveanu, 2000; Kimura et al., 2001; Helge, 2003; Hiscock, 2003). Several factors including type, intensity and duration of physical work have been shown to influence this effect (Ostrowski et al., 1998a, Ostrowski et al., 1998b, Ostrowski et al., 1999; Kimura, 2001). As described in the preceding section TNF- $\alpha$, IL-1 $1 \beta$, and IFN- $\gamma$ are all known to cause inflammation and an 
increase in algesic compounds such as $\mathrm{PGE}_{2}$. Concentrations of anti-inflammatory and inflammation-sensitive IL-6, IL-1Ra, and IL-10 would then increase in response to the surge of pro-inflammatory cytokines.

Exercise-induced increases in inflammatory cytokines can result in muscle and body soreness that can affect an athlete's ability to perform at peak potential. A reasonable hypothesis, therefore, is that decreasing the levels of these cytokines would increase athletic performance.

\section{The horse as a human analog in exercise trials}

There is ample evidence in the literature that horses make adequate surrogates for humans in exercise trials (Hinchcliff and McKeever, 1996; Farris, 1998; Hinchcliff and McKeever, 1998; McKeever et al., 1998; Kearns et al., 2001; Kearns et al., 2002). Firstly, it has been well demonstrated that horses and humans have comparable cardiovascular, thermoregulatory (i.e. sweating), immunological, endocrine, and inflammatory responses to exercise (McKeever, 1993; McKeever and Hinchcliff, 1995; Horohov, 1996; McKeever \& Malinowski, 1997; Farris, 1998; Horohov, 1999; Kohn, 1999; McKeever and Malinowski, 1999; Betros, 2002; Malinowski, 2002). Possibly most important to the issue at hand, horses also have similar upregulation of cytokines during and after exercise (Barton et al., 2003; Donovan et al., 2007). Controlling as many aspects of a study as possible is vital to the validity and repeatability of the experiment. Using a high-speed horse treadmill researchers are able to mimic various human exercise paradigms, from a short but intense sprint to a much longer and slower paced endurance run, in a controlled environment (Bayly, 1987; McKeever et al., 1993; McKeever \& Hinchcliff, 1995; Farris, 1998; Kearns \& McKeever, 2002; Ainsworth, 2003; Malinowski, 2004). 


\section{Quercetin}

Quercetin is a flavonoid found in a variety of edible plants, including numerous berries, onions, apples, tea leaves, and broccoli. Recent studies have shown that it may have great potential for treatment of inflammatory disorders. The reported effects of quercetin in the literature are multifold.

In vitro studies consistently show reductions in inflammatory and inflammationresponsive cytokines in cultures of immune cells after treatment with quercetin.

Decreases in the levels of TNF- $\alpha$, IL-1, IL-6, and nitric oxide (NO) are regularly reported (Comalada et al., 2005; Comalada et al., 2006; Kempuraj et al., 2006; Kaneko et al., 2008; Okoko and Oruambo, 2009). Increases in the level of the anti-inflammatory cytokine IL-10 have also been shown, but do not follow a dose-response curve (Comalada et al., 2006). These experiments were performed in a variety of mouse and human cells, including bone marrow-derived macrophages, pulmonary epithelial cells, mast cells, and lymphoma-derived monocytes (U937 cell line), indicating that the results should correlate well between cell types.

In vivo studies have been less decisive. Frequently no effect is noted, which could be due to various circumstances. Obviously insufficient exposure to quercetin due to poor absorption and/or insufficient dosage will result in a negative outcome. Another hypothesis deals with the fact that a rat colitis model is commonly used in chronic inflammation studies. As quercetin is absorbed in the small intestine, little if any of the flavonoid would make it to the colon (Comalada et al., 2005). But recent studies have produced more encouraging data. A study using a Helicobacter pylori-induced ulcer 
model in guinea pigs found that orally-dosed quercetin can inhibit inflammation, and greatly inhibited neutrophil infiltration (González-Segovia et al., 2008). In a murine asthma model, treatment with the flavonoid reduced the presence of neutrophils, eosinophils, lymphocytes, and macrophages in BAL fluid (Park et al., 2009). In fact, total cell numbers were reduced 10-fold in the quercetin group when compared to control.

Much research has been done attempting to determine quercetin's method of action. It seems clear that the pathway involves nuclear factor- $\kappa \mathrm{B}(\mathrm{NF}-\kappa \mathrm{B})$, a theory which will be explored more deeply in following paragraphs. NF- $\mathrm{B}$ is both activated by and induces transcription of inflammatory cytokines in a positive-feedback loop. NF- $\mathrm{B}$ normally exists in the cytosol as a heterodimer complexed with the inhibitory protein IкB. External stimuli, such as inflammatory cytokines, bacterial or viral antigens, or lipopolysaccharides (LPS) activate receptors on the cell surface. This begins a cascade in which protein kinase $\mathrm{C}(\mathrm{PKC})$ ultimately phosphorolates $\mathrm{I} \kappa \mathrm{B}$, causing its degradation by proteasomes. The disinhibited NF- $\mathrm{BB}$ complex enters the nucleus, where it induces transcription of specific genes with activation sites "keyed" to NF- $\kappa$ B, including TNF- $\alpha$ and IL-1 (Manning and Anderson, 1994; Baldwin, 1996; Baeuerle and Baichwal, 1997). In vitro studies have repeatedly shown that quercetin inhibits the phosphorylation and degradation of IкB (Comalada et al., 2005; Comalada et al., 2006; Nair et al., 2006; Kaneko et al., 2008; Ying et al., 2009), which could explain the reduction in levels of TNF- $\alpha$ and other inflammatory cytokines triggered by disinhibited NF- $\kappa$ B. Conversely when the cell surface receptor-induced cascade is bypassed and PKC is activated directly, the effect of quercetin is nullified (Kaneko et al., 2008). The same paper hypothesized an explanation for this occurrence: quercetin disrupts the formation of lipid rafts on the cell's 
surface. Lipid rafts accumulate in response to stimulation and mediate signal transduction (Simons and Toomre, 2000). They have also been shown to be essential for TNF- $\alpha$ induced activation of NF- $\mathrm{KB}$ (Legler et al., 2003). The method by which quercetin disrupts the formation of these rafts has yet to be described.

\section{Conclusion}

There seems little doubt that relationships between exercise, immune function, inflammation, and cytokines exist. As previously described, conventional treatments for pain and inflammation, such as COX antagonists, may have deleterious side effects. There is a paucity of information concerning the use of other anti-inflammatory compounds to offset the negative physiological results of exercise and possibly improve performance. Therefore the end goal of this study will be to test the hypothesis that quercetin, in sufficient dosage, can improve markers of athletic performance and reduce exercise-induced increases of inflammatory and inflammation-sensitive cytokines (TNF$\alpha$, IL-1ß, IL-6, IFN- $\gamma$, and the protease GrB) in horses. 


\section{References:}

1. Ainsworth, D., Appleton, J., Eicker, S., Luce, R., Flaminio, M., Antczak, D., 2003. The effect of strenuous exercise on mRNA concentrations of interleukin-12, interferon-gamma and interleukin-4 in equine pulmonary and peripheral blood mononuclear cells. Veterinary Immunology and Immunopathology 91, 61-71

2. Akira, S., Taga, T., Kishimoto, T., 1993. Interleukin-6 in biology and medicine. Advances in Immunology 54, 1-78

3. Amani, Y., Lee, S., Allison, A., 1993. Inhibition by glucocorticoids of the formation of interleukin-1 alpha, interleukin-1 beta, and interleukin-6: mediation by decreased mRNA stability. Molecular Pharmacology 43, 176-182

4. Baeuerle, P., Baichwal, V., 1997. NF-кB as a frequent target for immunosuppressive and anti-inflammatory molecules. Advances in Immunology $65,111-137$

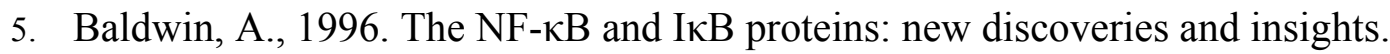
Annual Review of Immunology 14: 141-179

6. Bancroft, G., Schreiber, R., Unanue, E., 1991. Natural immunity, a T-cellindependent pathway of macrophage activation, defined in the scid mouse. Immunological Reviews 124, 5-24

7. Barton, B., 1997. IL-6: Insights into novel biological activities. Clinical Immunology and Immunopathology 85, 16-20

8. Barton, M., Williamson, L., Jacks, S., Norton, N., 2003. Effects on plasma endotoxin and eicosanoid concentrations and serum cytokine activities in horses competing in a 48-, 83-, or 159-km endurance ride under similar terrain and weather conditions. American Journal of Veterinary Research 64, 754-761

9. Bayly, W., Schulz, D., Hodgson, D, Gollnick, P., 1987. Ventilatory responses of the horse to exercise: effect of gas collection systems. Journal of Applied Physiology 63, 1210-1217

10. Belosevic, M., Davis, C., Meltzer, M., Nacy, C., 1988. Regulation of activated macrophage antimicrobial activities: identification of lymphokines that cooperate with IFN-gamma for induction of resistance to infection. Journal of Immunology $141,890-896$

11. Berke, G., 1995a. The CTL's kiss of death. Cell 81, 9-12

12. Berke, G., 1995b. Unlocking the secrets of CTL and NK cells. Immunology Today $16,343-346$ 
13. Bertrand, V., Guimbaud, R., Tulliez, M., Mauprivez, C., Sogni, P., Couturier, D., Giroud, J., Chaussade, S., Chauvelot-Moachon, L., 1998. Increase in tumor necrosis factor- $\alpha$ production linked to the toxicity of indomethacin for the rat small intestine. British Journal of Pharmacology 124, 1385-1394

14. Bethin, K., Vogt, S., Muglia, L., 2000. Interleukin-6 is an essential, corticotrophin releasing hormone-independent stimulator of the adrenal axis during immune system activation. Proceedings of the National Academy of Science of the USA 97, 9317-9322

15. Betros, C., McKeever, K., Kearns, C., Malinowski, K., 2002. Effects of aging and training on maximal heart rate and $\mathrm{VO}_{2} \max$. Equine Veterinary Journal 34, 100105

16. Beutler, B., Cerami, A., 1987. The endogenous mediator of endotoxic shock. Clinical Research 35, 192-197

17. Boehm, U., Klamp, T., Groot, M., Howard, J., 1997. Cellular responses to interferon-gamma. Annual Review of Immunology 15, 749-795

18. Bratke, K., Bottcher, B., Leeder, K., Schmidt, S., Kupper, M., Virchow, J., Luttman, W., 2004. Increase in granzyme B lymphocytes and soluble granzyme B in bronchoalveolar lavage of allergen challenged patients with atopic asthma. Clinical and Experimental Immunology 136, 542-548

19. Brooks, G., 1988. Blood Lactic Acid: Sports "Bad Boy" Turns Good. Sports Science Exchange 1

20. Bruunsgaard, H., Galbo, H., Halkjaer-Kristensen, J., Johansen, T., MacLean, D., Pedersen, B., 1997. Exercise-induced increase in serum interleukin-6 in humans is related to muscle damage. Journal of Physiology 499, 833-841

21. Buchmeier, M., Schreiber, R., 1985. Requirement of endogenous interferongamma production for resolution of Listeria monocytogenes infection.

Proceedings of the National Academy of Science of the USA 82, 7404-7408

22. Camussi, G., Lupia, E., 1998. The future role of anti-tumour necrosis factor (TNF) products in the treatment of rheumatoid arthritis. Drugs 55, 613-620

23. Cerretti, D., Kozlosky, C., Mosley, B., Nelson, N., Van Ness, K., Greenstreet, T., March, C., Kronheim, S., Druck, T., Cannizzaro, L., Huebner, K., Black, R., 1992. Molecular cloning of the IL-1ß processing enzyme. Science 256, 97-100

24. Colotta, F., Dower, S., Sims, J., Mantovani, A., 1994. The type II decoy receptor: a novel regulatory pathway for interleukin-1. Immunology Today $15,562-566$ 
25. Comalada, M., Camuesco, D., Sierra, S., Ballester, I., Xaus, J., Gálvez, J., Zarzualo, A., 2005, In vivo quercitrin anti-inflammatory effect involves release of quercetin, which inhibits inflammation through down-regulation of the NK- $\kappa B$ pathway. European Journal of Immunology 35, 584-592

26. Comalada, M., Ballester, I., Bailón, E., Sierra, S., Xaus, J., Gálvez, J., Sánchez de Madina, F., Zarzualo, A., 2006. Inhibition of pro-inflammatory markers in primary bone marrow-derived mouse macrophages by naturally occurring flavonoids: Analyss of the structure-activity relationship. Biochemical Pharmacology 72, 1010-1021

27. Coudreuse, J.M., Dupont, P., Nicol, C., 2004 Delayed post effort muscle soreness. Annales de Readaptation et de Medecine Physique 47, 290-298

28. Croisier, J.L., Camus, G., Deby-Dupont, G., Bertrand, F., Lhermerout, C., Crielaard, J., Juchmes-Ferir, A., Deby, C., Albert, A., Lamy, M., 1996. Myocellular enzyme leakage, polymorphonuclear neutrophil activation and delayed onset muscle soreness induced by isokinetic eccentric exercise. Archives of Physiology and Biochemistry 104, 322-329

29. Dalton, D., Pitts-Meek, S., Keshav, S., Figari, I., Bradley, A., Stewart, T., 1993. Multiple defects of immune function in mice with disrupted interferon-gamma genes. Science 259, 1739-1742

30. Dinarello, C., 1996. Biologic basis for interleukin-1 in disease. Blood 87, 20952147

31. Endres, S., Whitaker, R., Ghorbani, R., Meydani, S., Dinarello, C., 1996. Oral aspirin and ibuprofen increase cytokine-induced systhesis of IL-1ß and of tumour necrosis factor- $\alpha$ ex vivo. Immunology $87,264-270$

32. Englemann, H., Novick, D., Wallach, D., 1990. Two tumor necrosis factorbinding proteins purified from human urine. Evidence for immunological crossreactivity with cell surface tumor necrosis factor receptors. Journal of Biological Chemistry 265, 1531-1536

33. Evans, W., Cannon, J., 1991. The metabolic effects of exercise-induced muscle damage. Exercise and Sport Sciences Reviews 19, 99-125

34. Farrar, M., Schreiber, R., 1993. The molecular cell biology of interferon-gamma and its receptor. Annual Review of Immunology 11, 571-611

35. Farris, J., Hinchcliff, K., Mckeever, K., Lamb, D., Thompson, D., 1998. Effect of Tryptophan and of glucose on exercise capacity of horses. Journal of Applied Physiology 85, 807-816 
36. Febbraio, M., Pedersen, B., 2002. Muscle-derived interleukin-6: mechanisms for activation and possible biological roles. The FASEB Journal 16, 1335-1347

37. Ferrier, K., Nestel, P., Taylor, A., Drew, B., Kingwell, B., 2004. Diet but not exercise training reduces skeletal muscle TNF-alpha in overweight humans. Diabetologia 47, 630-637

38. Froelich, C., Dixit, V., Yang, X., 1998. Lymphocyte granule-mediated apoptosis: matters of viral mimicry and deadly proteases. Immunology Today 19, 30-36

39. González-Segovia, R., Quintanar, J., Salinas, E., Ceballos-Salazar, R., AvilesJiménez, F., Torres-López, J., 2008. Effect of the flavonoid quercetin on inflammation and lipid peroxidation induced by Helicobacter pylori in gastric mucosa of guinea pig. Journal of Gastroenterology 43, 441-447

40. Gronich, J., Konieczkowski, M., Gelb, M., Nemenoff, R., Sedor, J., 1994. Interleukin- $1 \alpha$ causes a rapid activation of cytosolic phospholipase $\mathrm{A}_{2}$ by phosphorylation in rat mesangial cells. Journal of Clinical Investigation 93, 1224 1233

41. Hazuda, D., Strickler, J., Kueppers, F., Simon, P., Young, P., 1990. Processing of precursor interleukin-1 beta and inflammatory disease. Journal of Biological Chemistry 265, 6318-6322

42. Helge, J., Stallknecht, B., Pedersen, B., Galbo, H., Kiens, B., Richter, E., 2003. The effect of graded exercise on Il-6 release and glucose uptake in human skeletal muscle. Journal of Physiology 546, 299-305

43. Hinchcliff, K., McKeever, K., Muir, W., Sams, R., 1996. Furosemide reduces accumulated oxygen deficit in horses during brief intense exertion. Journal of Applied Physiology 81, 1550-1554

44. Hinchcliff, K., McKeever, K., 1998 Fluid administration attenuates the haemodynamic effect of frusemide in running horses. Equine Veterinary Journal $30,246-250$

45. Hirano, T., 1992. The biology of interleukin-6. Chemical Immunology 51, $153-$ 180

46. Hiscock, N., Petersen, E., Krzywkowski, K., Boza, J., Halkjaer-Kristensen, J., Pedersen, B., 2003. Glutamine supplementation further enhances exerciseinduced plasma IL-6. Journal of Applied Physiology 95, 145-148

47. Hohmann, H., Brockhaus, M., Baeuerle, P., Remy, R., Kolbeck, R., van Loon, A., 1990a. Expression of the types A and B tumor necrosis factor (TNF) receptors is 
independently regulated, and both receptors mediate activation of the transcription factor NF-kappa B. TNF alpha is not needed for induction of a biological effect via TNF receptors. Journal of Biological Chemistry 265, 22409-22417

48. Hohmann, H., Remy, R., Brockhaus, M., van Loop, A., 1990b. Tumor necrosis factors-alpha and -beta bind to the same two types of tumor necrosis factor receptors and maximally activate the transcription factor NF-kappa B at low receptor occupancy and within minutes after receptor binding. Journal of Biological Chemistry 265, 15183-15188

49. Horohov, D., Keadle, T., Pourciau, S., Littlefield-Chabaud, M., Kamerling, S., Keowen, M., French, D., Melrose, P., 1996. Mechanism of exercise-induced augmentation of lymphokine activated killer (LAK) cell activity in the horse. Veterinary Immunology and Immunopathology 53, 221-233

50. Horohov, D., Dimock, A., Guirnalda, P., Folsom, R., McKeever, K., Malinowski, K., 1999. Effect of Exercise on the immune response of young and old horses. American Journal of Veterinary Research 60, 643-647

51. Huang, S., Hendriks, W., Althage, A., Hemmi, S., Bluethmann, H., Kamijo, R., Vilcek, J., Zinkernagel, R., Aguet, M., 1993. Immune response in mice that lack the interferon-gamma receptor. Science 259, 1742-1745

52. Kagi, D., Ledermann, B., Burki, K., Zinkernagel, R., Hengartner, H., 1996. Molecular mechanisms of lymphocyte-mediated cytotoxicity and their role in immunological protection and pathogenesis in vivo. Annual Review of Immunology 14, 207-232

53. Kaneko, M., Takimoto, H., Sugiyama, T., Seki, Y., Kawaguchi, K., Kumazawa, Y., 2008. Suppressive effects of the flavonoids quercetin and luteolin on the accumulation of lipid rafts after signal transduction via receptors. Immunopharmacology and Immunotoxicology 30, 867-882

54. Kaplan, D., 1996. Autocrine secretion and the physiologic concentration of cytokines. Immunology Today 17, 303-304

55. Kaplanski, G., Farnarier, C., Kaplanski, S., Pora, R., Shapiro, L., Bongrand, P., Dinarello, C., 1994. Interleukin-1 induces interleukin-8 secretion from endothelial cells by a juxtacrine mechanism. Blood $84,4242-4248$

56. Kearns, C., McKeever, K., Malinowski, K., Struck, M., Abe, T., 2001. Chronic administration of therapeutic levels of clenbuterol acts as a repartitioning agent. Journal of Applied Physiology 91, 2064-2070

57. Kearns, C., McKeever, K., 2002. Clenbuterol diminishes aerobic performance in horses. Medicine and Science in Sports and Exercise 34, 1976-1985 
58. Kempuraj, D., Castellani, M., Petrarca, C., Conti, P., Theoharides, T., Vecchiet, J., 2006. Inhibitory effect of quercetin on tryptase and interleukin-6 release, and histamine decarboxylase mRNA transcription by human mast cell-1 cell line. Clinical and Experimental Medicine 6, 150-156

59. Kimura, H., Suzui, M., Nagao, F., Matsumoto, K., 2001. Highly sensitive determination of plasma cytokines by time-resolved fluroimmunoassay; Effect of bicycle exercise on plasma level of interleukin-1alpha (IL-1alpha), Tumor necrosis factor alpha (TNF-alpha), and Interferon Gamma (IFN gamma). Analytical Sciences 17, 593-597

60. Kohn, C., Hinchcliff, K., McKeever, K., 1999. Evaluation of washing with cold water to facilitate heat dissipation in horses exercised in hot, humid conditions. American Journal of Veterinary Research 60, 299-305

61. Kopf M., Baumann, H., Freer, G., Freudenberg, M., Lamers, M., Kishimoto, T., Zinkernagel, R., Bluethmann, H., Köhler, G., 1994. Impaired immune and acutephase responses in interleukin-6-deficient mice. Nature 368, 339-342

62. Kordula, T., Rokita, H., Koj, A., Fiers, W., Gauldia, J., Baumann, H., 1991. Effects of interleukin-6 and leukemia inhibitory factor on the acute phase response and DNA synthesis in cultured rat hepatocytes. Lymphokine and Cytokine Research 19, 23-26

63. Kuno, K., Matsushima, K., 1994. The IL-1 receptor signaling pathway. Journal of Leukocyte Biology 56, 542-547

64. Lauw, F., Simpson, A., Hack, C., Prins, J., Wolbink, A., van Deventer, S., Chaowagul, W., White, N., van der Poll, T., 2000. Soluble granzymes are released during human endotoxemia and in patients with severe infection due to gramnegative bacteria. Journal of Infectious Diseases 182, 206-213

65. Legler, D., Micheau, O., Doucey, M., Tschopp, J., Bron, C., 2003. Recruitment of TNF receptor 1 to lipid rafts is essential for TNF- $\alpha-$ mediated NF- $\kappa$ B activation. Immunity 18, 655-665

66. Lenczowski, M., Van Dam, A., Poole, S., Larrick, J., Tilders, F., 1997. Role of circulating endotoxin and interleukin-6 in the ACTH and corticosterone response to intraperitoneal LPS. The American Journal of Physiology 274, R1870-1877

67. Malinowski, K., Betros, C., Flora, L., Kearns, C., McKeever, K, 2002. Effect of training on age-related changes in plasma insulin and glucose. Equine Veterinary Journal 34, 147-153 
68. Malinowski, K., Kearns, C., Giurnalda, P., Roegner, V., McKeever, K. 2004. Effect of chronic clenbuterol administration and exercise training on immune function in horses. Journal of Animal Science 82, 3500-3507

69. Manning, A., Anderson, D., 1994. Transcription factor NF-кB: an emerging regulator or inflammation. Annual Reports in Medicinal Chemistry 29, 235-244

70. Mastorakos, G., Choursos, G., Weber, J., 1993. Recombinant interleukin-6 activates the hypothalamic-pituitary-adrenal axis in humans. Journal of Clinical Endocrinology and Metabolism 77, 1690-1694

71. McKeever, K., Hinchcliff, K., Gerken, D., Sams, R., 1993. Effects of cocaine on incremental treadmill exercise in horses. Journal of Applied Physiology 75, 2727 2733

72. McKeever, K., Hinchcliff, K., 1995. Neuroendocrine control of blood volume, blood pressure and cardiovascular function in horses. Equine Veterinary Journal $18,77-81$

73. McKeever, K., Malinowski, K., 1997. Exercise capacity in young and old mares. American Journal of Veterinary Research 58, 1468-1472

74. McKeever, K., Malinowski, K., Christensen, R., Hafs, H., 1998. Chronic Recombinant Equine Somatotropin (eST) administration does not affect aerobic capacity or exercise performance in geriatric mares. The Veterinary Journal 155, $19-25$

75. McKeever, K., Malinowski, K., 1999. Endocrine response to exercise in young and old horses. Equine Veterinary Journal 30, 561-566

76. Metkar, S., Menaa, C., Pardo, J., Wang, B., Wallich, R., Freudenberg, M., Kim, S., Raja, S., Shi, L., Simon, M., Froelich, C., 2008. Human and mouse granzyme A induce a proinflammatory cytokine response. Immunity 29, 720-733

77. Moldoveanu, A., Shephard, R., Shek, P., 2000. Exercise elevates plasma levels but not gene expression of Il-1Beta, IL-6, and TNF-alpha in blood mononuclear cells. Journal of Applied Physiology 89, 1499-1504

78. Nacy, C., Fortier, A., Meltzer, M., Buchmeier N., Schreiber R., 1985. Macrophage activation to kill Leishmania major: activation of macrophages for intracellular destruction of amastigotes can be induced by both recombinant interferon-gamma and non-interferon lymphokines. Journal of Immunology 135, $3505-3511$

79. Nair, M., Mahajan, S., Reynolds, J., Aalinkeel, R., Nair, H., Schwartz, S., Kandaswami, C., 2006. The flavonoid quercetin inhibits proinflammatory 
cytokine (tumor necrosis factor alpha) gene expression in normal peripheral blood mononuclear cells via modulation of the NF- $\mathrm{kB}$ system. Clinical and Vaccine Immunology 13, 319-328

80. Nathan, C., Murray, H., Wiebe, M., Rubin, B., 1983. Identification of interferongamma as the lymphokine that activates human mactophage oxidative metabolism and antimicrobial activity. Journal of Experimental Medicine 158, 670-689

81. Okoko, T., Oruambo, I., 2009. Inhibitory activity of quercetin and its metabolite on lipopolysaccharide-induced activation of macrophage U937 cells. Food and Chemical Toxicology 47, 809-812

82. O'Neill, L., 1995. Towards an understanding of the signal transduction pathways for interleukin-1. Biochimica et Biophysica Acta 1266, 31-44

83. Ostrowski, K., Rhode, T., Zacho, M., Asp, S, Pedersen, B., 1998a. Evidence that interleukin-6 is produced in human skeletal muscle during prolonged running. Journal of Physiology 508, 949-953

84. Ostrowski, K., Hermann, C., Bangash, A., Schjerling, P., Nielsen, J., Pedersen, B., 1998b. A trauma-like elevation of plasma cytokines in humans in response to treadmill running. Journal of Physiology 513, 889-894

85. Ostrowski, K., Rohde, T., Asp, S., Schjerling, P., Pedersen, B., 1999. Pro- and anti-inflammatory cytokine balance in strenuous exercise in humans. Journal of Physiology 515, 287-297

86. Park, H., Lee, C., Jung, I., Lee, J., Jeong, J., Chang, J., Chun, S., Kim, M., Choi., I., Ahn, S., Shin, Y., Yeom, S., Park, Y., 2009. Quercetin regulates Th1/Th2 balance in a murine model of asthma. International Immunopharmacology 9, 261267

87. Pedersen, B., Hoffman-Goetz, L., 2000. Exercise and the Immune Sytem: Regulation, Integration, and Adaptation. Physiological Reviews. 80, 1055-1081

88. Raber, J., O'Shea, R., Bloom, F., Campbell, I., 1997. Modulation of hypothalamic-pituitary-adrenal function by transgenic expression of interleukin-6 in the CNS of mice. Journal of Neuroscience 17, 9473-9480

89. Saghizadeh, M., Ong, J., Garvey, W., Henry, R., Kern, P., 1996. The expression of TNF-alpha by human muscle. Relationship to insulin resistance. Journal of Clinical Investigation 97, 1111-1116

90. Schmid, E., Binder, K., Frell, M., Scheurich, P., Pfizenmaier, K., 1995. Both tumor necrosis factor receptors, TNFR60 and TNFR80, are involved in signaling 
endothelial tissue factor expression by juxtacrine tumor necrosis factor alpha. Blood 86, 1836-1841

91. Sehgal, P., 1990. Interleukin-6: a regulator of plasma protein gene expression in hepatic and non-hepatic tissues. Molecular Biology and Medicine 7, 117-130

92. Shalaby, M., Waage, A., Aarden, L., Espevik, T., 1989. Endotoxin, tumor necrosis factor-alpha and interleukin 1 induce interleukin 6 production in vivo. Clinical Immunology and Immunopathology 53, 455-498

93. Shresta, S., Graubert, T., Thomas, D., Raptis, S., Ley, T., 1999. Granzyme A initiates an alternative pathway for granule-mediated apoptosis. Immunity 10, 595-605

94. Shi, L., Ka, C., Powers, J., Aebersold, R., Greenberg, A., 1992. Purification of three cytotoxic lymphocyte granule serine proteases that induce apoptosis through distinct substrate and target cell interactions. Journal of Experimental Medicine $176,1521-1529$

95. Simons, K., Toomre, D., 2000. Lipid rafts and signal transduction. Nature Reviews Molecular Cell Biology 2, 216

96. Slomiany, B., Piotrowski, J., Slomiany, A., 1997. Induction of tumor necrosis factor- $\alpha$ and apoptosis in gastric mucosal injury by indomethacin: effect of omeprazole and ebrotidine. Scandinavian Journal of Gastroenterology 32, 638642

97. Smyth, M., Trapani, J., 1995. Granzymes: exogenous proteinases that induce target cell apoptosis. Immunology Today 16, 202-206

98. Snow, D.H., Valberg, J. 1994. Muscle Anatomy, Physiology, and Adaptations to Exercise and Training. In: Hodgson, D.R., and R.J. Rose (Eds.), The Athletic Horse: Principles and Practice of Equine Sports Medicine. W.B. Saunders Company, Philadelphia, PA, USA, pp. 146-179

99. Sower, L., Klimpel, G., Hanna, W., Froelich, C., 1996. Extracellular activities of human granzymes. I. Granzyme A induces IL6 and IL8 production in fibroblast and epithelial cell lines. Cellular Immunology 171, 159-163

100.Spaeny-Dekking, E., Hanna, W., Wolbink, A., Wever, P., Kummer, J., Swaak, A., Middeldorp, J., Huisman, H., Froelich, C., Hack C., 1998. Extracellular granzymes $\mathrm{A}$ and $\mathrm{B}$ in humans: detection of native species during CTL responses in vitro and in vivo. Journal of Immunology 160, 3610-3616 
101.Starkie, R., Ostrowski, S., Jauffred, S., Febbraio, M., Pedersen, B., 2003. Exercise and IL-6 infusion inhibit endotoxin-induced TNF-alpha production in humans. The FASEB Journal 17, 884-886

102.Suzuki, Y., Orellana, M., Schreiber, R., Remington, J., 1988. Interferon-gamma: the major mediator of resistance against Toxoplasma gondii. Science 240, 516518

103.Tak, P., Spaeny-Dekking, L., Kraan, M., Breedveld, F., Froelich, C., Hack, C., 1999. The levels of soluble granzyme A and B are elevated in plasma and synovial fluid of patients with rheumatoid arthritis (RA). Clinical and Experimental Immunology 116, 366-370

104.Thornberry, N., Bull, H., Calaycay, J., Chapman, A., Howard, M., Kostura, D., Miller, S., Molineaux, J., Weidner, J., Aunins, J., Elliston, K., Ayala, J., Casano, F., Chin, J., Ding, G., Egger, L., Gaffney, E., Limjuco, G., Palyha, O., Raju, S., Rolando, A., Salley, J., Yamin, T., Lee, T., Shively, J., MacCross, M., Mumford, R., Schmidt, J., Tocci, M., 1992. A novel heterodimeric cysteine protease is required for interleukin-1 beta processing in monocytes. Nature 356, 768-774

105.Tilg, H., Dinarello, C., Mier, J., 1997. IL-6 and APPs: anti-inflammatory and immunosuppressive mediators. Immunology Today 18, 428-432

106.Toft, A., Jensen, L., Bruunsgaard, H., Ibfelt, T., Halkjaer-Kristensen, J., Febbraio, M., Pedersen, B., 2002. Cytokine response to eccentric exercise in young and elderly humans. American Journal of Physiology - Cell Physiology 283, C289C295

107.Trappe T., Fluckey J., White F., Lambert C., Evans W., 2001. Skeletal muscle PGF(2)(alpha) and PGE(2) in response to eccentric resistance exercise: influence of ibuprofen acetaminophen. Journal of Clinical Endocrinology and Metababolism 86, 5067-5070

108.Tripp, C., Wolf, S., Unanue, E., 1993. Interleukin-12 and tumor necrosis factor alpha are costimulators of interferon-gamma production by natural killer cells in severe combined immunodeficiency mice with listeriosis, and interleukin-10 is a physiologic antagonist. Proceedings of the Natural Academy of Sciences of the USA 90, 3725-3729

109.Unanue, E., 1997. Interrelationship among macrophages, NK cells and neutrophils in early stages of Listeria resistance. Current Opinion in Immunology $9,35-43$

110. Van Snick, J., 1990. Interleukin-6: an overview. Annual Review of Immunology $8,253-278$ 
111.Waage, A., Slupphaug, G., Shalaby, R., 1990. Glucocorticoids inhibit the production of IL6 from monocytes, endothelial cells and fibroblasts. European Journal of Immunology 20, 2439-2443

112.Watanabe, N., Kobayashi, Y., 1994. Selective release of a processed form of interleukin-1 $\alpha$. Cytokine 6, 597-601

113.Ying, B., Yang, T., Song, X., Hu, X., Fan, H., Lu, X., Chen, L., Cheng, D., Wang, T., Liu, D., Xu, D., Wei, Y., Wen, F., 2009. Quercetin inhibits IL-1 beta-induced ICAM-1 expression in pulmonary epithelial cell line A549 through the MAPK pathways. Molecular Biology Reports 36, 1825-1832 


\section{Chapter 2: \\ Effects of quercetin on exercise potential and exercise-induced cytokines in the horse.}

\section{$\underline{\text { Introduction }}$}

Inflammation, the common physiological response to a wide variety of injuries and irritations, has been studied in one form or another for literally thousands of years. Hippocrates is credited with writing about using willow leaves to treat labor pains and inflammation of joints in the $4^{\text {th }}$ century B.C.E., and even then it was already common practice. We now know that willow contains the compound salicin, which once purified and bound to an acetyl group, is better known as aspirin.

Since Bayer first marketed aspirin in 1899 , scientists have continued to delve deeper into the causes of inflammation. Most non-steroidal anti-inflammatory drugs (NSAIDS), including aspirin, work by inhibiting the production of prostaglandins (PG) via inactivation or modification of the cyclooxygenase (COX) enzyme. Unfortunately the inflammatory cascade is very complex, and disruption of the COX pathway can have unintended consequences.

For example, tumor necrosis factor alpha (TNF- $\alpha)$ is an inflammatory cytokine produced by many cell types within the body, though primarily by macrophages. TNF- $\alpha$ initiates several inflammatory pathways, including the formation of the inflammatory lipid $\mathrm{PGE}_{2}$ via the COX enzyme. The rising $\mathrm{PGE}_{2}$ levels inhibit further TNF- $\alpha$ release in a negative feedback loop. In the case of NSAID antagonism of the COX enzyme, the inhibition of $\mathrm{PGE}_{2}$ formation precludes the negative feedback loop from occurring. Thus TNF- $\alpha$ levels rise (Endres et al., 1996; Slomiany et al., 1997; Bertrand et al., 1998), and the other inflammatory pathways triggered by the cytokine, including nuclear factor 
kappa-light-chain-enhancer of activated B cells (NF- $\mathrm{kB})$ and mitogen-activated protein kinase (MAPK), continue to function. Ironically some of the diseases commonly treated by NSAIDS, such as rheumatoid arthritis, are thought to be caused by overproduction of TNF- $\alpha$ (Camussi and Lupia, 1998). Clearly a method for directly inhibiting the action of TNF- $\alpha$ and other inflammatory cytokines could produce a variety of beneficial effects.

One possible use for such a treatment would be to combat the deleterious inflammatory effects of strenuous exercise. Myriad studies have linked exercise to a change in cytokine levels. Plasma concentrations of TNF- $\alpha$, IL-1ß, IL-1Ra, IL-6, IL-10, and IFN- $\gamma$ can increase in response to exercise in humans (Bruunsgaard et al., 1997; Ostrowski et al., 1998a, b; Ostrowski et al., 1999; Moldoveanu, 2000; Kimura et al., 2001; Helge, 2003; Hiscock, 2003). Several factors including type, intensity and duration of physical work have been shown to influence this effect (Ostrowski et al., 1998a, b; Ostrowski et al., 1999; Kimura, 2001). Exercise-induced increases in inflammatory cytokines can result in muscle and body soreness that can affect an athlete's ability to perform at peak potential. A reasonable hypothesis, therefore, is that decreasing the levels of these cytokines would increase athletic performance.

In vitro studies consistently show reductions in inflammatory cytokines in cultures of immune cells after treatment with quercetin, a flavonoid found in a variety of edible plants including numerous berries, onions, apples, tea leaves, and broccoli. Decreases in the levels of TNF- $\alpha$, IL-1, IL-6, and nitric oxide (NO) are regularly reported (Comalada et al., 2005; Comalada et al., 2006; Kempuraj et al., 2006; Kaneko et al., 2008; Okoko and Oruambo, 2009). Increases in the level of the anti-inflammatory cytokine IL-10 have also been shown, but do not follow a dose-response curve 
(Comalada et al., 2006). These experiments were performed in a variety of mouse and human cells, including bone marrow-derived macrophages, pulmonary epithelial cells, mast cells, and lymphoma-derived monocytes (U937 cell line), indicating that the results should correlate well between cell types.

In vivo studies have been less decisive. Frequently no effect is noted, which could be due to various circumstances. Obviously insufficient exposure to quercetin, due to poor absorption and/or insufficient dosage, will result in a negative outcome. Another hypothesis deals with the fact that a rat colitis model is commonly used in chronic inflammation studies. As quercetin is absorbed in the small intestine, little if any of the flavonoid would make it to the colon (Comalada et al., 2005). But recent studies have produced more encouraging data. A study using a Helicobacter pylori-induced ulcer model in guinea pigs found that orally-dosed quercetin can inhibit inflammation, and greatly inhibited neutrophil infiltration (González-Segovia et al., 2008). In a murine asthma model, treatment with the flavonoid reduced the presence of neutrophils, eosinophils, lymphocytes, and macrophages in bronchialalveoler lavage (BAL) fluid (Park et al., 2009). In fact, total cell numbers were reduced 10-fold in the quercetin group when compared to control.

Drawing upon the above conclusions and conjectures, we have formulated a new hypothesis: quercetin, in sufficient dosage, will increase athletic performance in the horse by decreasing exercise-induced inflammation via inhibition of the production of inflammatory cytokines. First, however, we must demonstrate that measurable levels of quercetin can be detected in the blood and muscle following oral administration of the flavonoid. 


\section{$\underline{\text { Materials and Methods }}$}

\section{Pharmacokinetics}

\section{Sample Collection:}

Two healthy, unfit Standardbred mares ( $\sim 500 \mathrm{~kg}$, age 4-5 years) were dosed via a nasogastric tube BID ( 8 am and $8 \mathrm{pm}$ ) with $6 \mathrm{~g}$ of quercetin in tap water for 3.5 days. Blood and muscle samples were collected just before the first dose, four hours after the 8 am dosing on days 1,2 , and 3 , and $0.5,1,2,4,8,12$, and 24 hours after the dose on day 4.

The blood samples were collected in vacuum tubes containing EDTA and centrifuged for $10 \mathrm{~min}$ at 10,000 rpm. $1 \mathrm{ml}$ aliquots of plasma were pipetted into cryotubes, and $100 \mu \mathrm{l}$ of $10 \%$ ascorbic acid (Sigma Aldrich) was added to each tube as a preservative (Erlund et al., 2003). The samples were vortexed and immediately frozen at $80^{\circ} \mathrm{C}$.

Muscle samples were taken from the gluteal muscle under aseptic conditions. Four local subcutaneous injections of lidocaine were made around the collection site to minimize discomfort to the horse. The skin and fascia were punctured with a \#11 scalpel blade to allow access to the muscle underneath. Samples were collected using a Bergstrom biopsy needle (6 mm, KRUUSE Worldwide Veterinary Supplier, Denmark) at a depth of $\sim 5 \mathrm{~cm} .50-200 \mathrm{mg}$ of muscle were collected with each sampling and were frozen immediately at $-80^{\circ} \mathrm{C}$. Following extraction of the sample the wound was closed with sterile suture. 
Processing of plasma samples:

To each stored sample containing $1 \mathrm{ml}$ plasma and $100 \mu \mathrm{l}$ ascorbic acid, $110 \mu \mathrm{l}$ of $0.78 \mathrm{M}$ sodium acetate ( $\mathrm{NaAc}$ ) (Sigma Aldrich) buffer ( $\mathrm{pH} 4.8$ ) was added. The NaAc is used to maintain a $\mathrm{pH}$ of 4.8 during hydrolysis of quercetin glucuronides and sulfate conjugates to quercetin. To this end, the NaAc is followed by the addition of $40 \mu 1$ of $B-$ glucuronidase/sulfatase (ß-glucuronidase activity of not less than 100,000 units/ml and sulfatase activity of not more than 7,500 units/ml) derived from Helix pomatia, HP-2 (Sigma Aldrich). $20 \mu \mathrm{l}$ of $100 \mu \mathrm{g} / \mathrm{ml}$ fisetin (Biochemica Fluka) in methanol was added as an internal standard (Chen et al., 2005). The mixture was incubated for 17 hours at $37^{\circ}$ C.

Following incubation, each sample was diluted with $2 \mathrm{ml}$ of $0.5 \mathrm{M}$ phosphoric acid, vortexed, and centrifuged for $10 \mathrm{~min}$ at 2,000 rpm. The resulting supernatant was subjected to a preconditioned Oasis HLB cartridge ( $1 \mathrm{cc} / 30 \mathrm{mg}$ packing, Waters Corp). The cartridge was mounted on a vacuum chamber and preconditioned with $1 \mathrm{ml}$ of methanol followed by $1 \mathrm{ml}$ of $0.5 \mathrm{M}$ phosphoric acid. The plasma supernatant was run through the cartridge, followed by $1 \mathrm{ml}$ of $0.5 \mathrm{M}$ phosphoric acid containing $5 \%$ methanol. These waste fluids were discarded and new tubes were placed in the vacuum chamber. $3 \mathrm{ml}$ of methanol were run through the cartridge and collected in a conical glass tube.

This eluate was evaporated to dryness in a nitrogen drying rack maintained at $30^{\circ}$ C. The residue obtained was dissolved in an additional $1 \mathrm{ml}$ of methanol and dried again. The residue from the $2^{\text {nd }}$ drying was dissolved in $20 \mu 1$ of methanol and vortexed. Onehundred $\mu 1$ of mobile phase ( $80 \%$ methanol, $20 \%$ water, $\mathrm{pH} 3.73$ ) was added and the 
sample was vortexed again. The resulting solution was transferred to an HPLC vial for analysis.

Blank samples of plasma were spiked with quercetin to obtain ratios of 10, 100, 200, 400, and $600 \mathrm{ng} / \mathrm{ml}$ quercetin/plasma. These ratios were used to construct a standard curve.

\section{Processing of muscle samples:}

This process is modified from de Boer et al. (2005).

While still frozen, $50 \pm 1 \mathrm{mg}$ of muscle were collected from each sample. $0.85 \mathrm{ml}$ of $0.5 \mathrm{M} \mathrm{NaAc}$ (pH 5.0, containing $28 \mathrm{mM}$ ascorbic acid), $12 \mu 1$ of $\beta-$ glucuronidase/sulfatase, and $20 \mu \mathrm{l}$ of $100 \mu \mathrm{g} / \mathrm{ml}$ fisetin in methanol were added. The mixture was thoroughly homogenized, then incubated for two hours at $37^{\circ} \mathrm{C}$. Following incubation, $0.85 \mathrm{ml}$ of $0.5 \mathrm{M}$ phosphoric acid was added. The mixture was vortexed, then centrifuged for $10 \mathrm{~min}$ at $3750 \mathrm{rpm} .1 \mathrm{ml}$ of the resulting supernatant was run through Oasis HLB cartridges and the eluate processed as with the plasma samples. Blank samples of lean ground beef, obtained from a grocery store, were spiked with quercetin to obtain ratios of 1,2 , and $3 \mathrm{ng} / \mathrm{mg}$ quercetin/muscle. These ratios were used to construct a standard curve.

HPLC analysis:

HPLC analysis was performed using an HP1100 with diode array detector and Agilent Chemstation software at a UV detection wavelength of $370 \mathrm{~nm}$. An injection volume of $20 \mu 1$ was used for plasma samples, while $50 \mu 1$ was used to adequately detect the lower quercetin concentrations in the muscle samples. Flow rate was $0.5 \mathrm{ml} / \mathrm{min}$, with a mobile 
phase of $80 \%$ methanol and $20 \%$ water, $\mathrm{pH}$ adjusted to 3.73 with acetic acid. The samples were processed through an HISIL PS phalanx C18 column $5 \mathrm{M}(250 \times 4.6) \mathrm{mm}$ with attached guard cartridge $(20 \times 3.2 \mathrm{~mm})$ (Nest Group, Inc) maintained at $30^{\circ} \mathrm{C}$. All reagents used were of HPLC grade.

\section{Pharmacodynamics}

Six healthy, unfit Standardbred mares were chosen for this study. Prior to dosing, a baseline blood sample was taken from each. In a manner identical to the PK procedure above, horses were dosed with either $6 \mathrm{~g}$ of quercetin or water ( $\mathrm{n}=3 \mathrm{each}$ ) for 3.5 days. Two hours after the seventh and final dose, the graded exercise test (GXT) was run as described below. Following a washout and healing period of 3 weeks the test was repeated in a crossover fashion. Horses that had previously been dosed with quercetin received water, and vice versa.

The GXT was designed to allow for measurement of maximal oxygen uptake and other factors indicative of exercise performance. Horses were fasted for $\sim 12 \mathrm{hrs}$ prior to the final dosing. On the morning of the test each horse was weighed and dosed with the appropriate treatment ( $6 \mathrm{mg}$ quercetin in $2 \mathrm{~L}$ water, or the water alone) at $\mathrm{T}=-2 \mathrm{hr}$. At approximately $\mathrm{T}=-15 \mathrm{~min}$ a catheter (Angiocath, 14 gauge) was inserted percutaneously into the left jugular vein using sterile techniques and local lidocaine anesthesia. At $\mathrm{T}=-5$ min the horse stood quietly on the treadmill (Sato I, Equine Dynamics, Inc., Lexington, $\mathrm{KY})$ while baseline calorimetry data and blood samples $(15 \mathrm{ml})$ were taken. Calorimetry data were collected by fitting the horse with an indirect open-flow calorimeter apparatus (Oxymax-XL, Columbus, $\mathrm{OH}$ ), which took recordings continuously at $10 \mathrm{sec}$ intervals. 
During the test the treadmill remained at a fixed $6 \%$ grade. At $\mathrm{T}=0$ the treadmill was started at a speed of $4 \mathrm{~m} / \mathrm{sec}$. A blood sample was collected during $\mathrm{T}=50-60 \mathrm{sec}$, and at $60 \mathrm{sec}$ the treadmill speed was increased to $6 \mathrm{~m} / \mathrm{sec}(5 \mathrm{~m} / \mathrm{sec}$ was omitted $)$. Each following minute the treadmill speed was increased by $1 \mathrm{~m} / \mathrm{sec}$, up to a maximum speed of $11 \mathrm{~m} / \mathrm{sec}$, and a blood sample was taken during the last $10 \mathrm{sec}$ at each speed. The test ended when the horse reached fatigue, defined as not being able to keep up with the treadmill despite humane encouragement. The finishing speed and the time spent running at the finishing speed were recorded.

Blood samples were also collected once the horse reached fatigue, at 2 and 30 min, and at 1, 2, 4, and 24 hrs after the conclusion of the test. All blood samples were placed into tubes containing EDTA (Vacutainer, Becton Dickson, Inc., Franklin Lakes, NJ) and kept on ice until the conclusion of the trial. A portion of each sample was analyzed in duplicate for hematocrit and total plasma protein concentration using the microhematocrit technique and refractometry (McKeever et al., 1988); the remainder of each sample was centrifuged for $10 \mathrm{~min}$ at 10,000 rpm. Resulting plasma was transferred to cryostat tubes and frozen at $-80^{\circ} \mathrm{C}$. This plasma was later tested for glucose, insulin, lactate, and electrolyte concentrations.

Muscle samples were collected as described in the PK procedure above at $0.5,1$, 2, 4, and $24 \mathrm{hrs}$ after the conclusion of the test. Each sample was divided into 3 sections, which were placed in cryostat tubes and immediately frozen at $-80^{\circ} \mathrm{C}$. Frozen samples of blood and muscle were sent to Dr. David Horohov in the Department of Veterinary 
Science at the University of Kentucky for measurement of mRNA expression for IL-1, IL-6, TNF- $\alpha$, IFN- $\gamma$, and granzyme-B (GrB).

Real Time-PCR (RT-PCR):

Samples were analyzed using real time-PCR for measurement of mRNA expression of IFN-gamma, IL-1, IL-6, TNF- $\alpha$, and GrB. Total RNA was isolated from the PAXgene tubes using the PAXgene RNA Blood Kit and RNA from tissue was isolated using phenolchloroform extraction (BioPhotometer). The RT reactions resulted in $80 \mu \mathrm{l}$ of cDNA, and each reaction consists of $16 \mu \mathrm{l}$ of AMV reverse transcription buffer (5x), $16 \mu \mathrm{l}$ of $\mathrm{MgCl} 2,4 \mu \mathrm{l}$ of dNTP, $1 \mathrm{ml}$ RNasin, $1 \mathrm{ml}$ Oligo dT primer, and 0.5 $\mathrm{ml}$ of AMV Reverse Transcriptase in addition to the $1 \mu \mathrm{g}$ of RNA. Cytokine-specific cDNA was amplified and quantitated by 'real-time' PCR (ABI 7500HT Fast Real-Time PCR System), using the Taq thermostable DNApolymerase and primers based on the sequences for equine cytokines and $\beta$-glucoronidase. Specific primers and FAM-labeled probes for IFN- $\gamma$, TNF- $\alpha$, IL-6, IL-1, GrB, and $\beta$-glucoronidase provided as kits (ABI, Assay-by-Design) were added to $10 \mathrm{ml}$ reactions in 384-well plates, which consisted of 5 $\mathrm{ml}$ of TaqMan Gene Expression Master Mix (ABI), 0.5 of primer-probe and 4.5 of cDNA. The following PCR conditions were employed: $95^{\circ} \mathrm{C}$ for 10 mins followed by 40 cycles of $95^{\circ} \mathrm{C}$ for $15 \mathrm{~s}$ and $60^{\circ} \mathrm{C}$ for $60 \mathrm{~s}$, as recommended by the manufacturer. Differences in RNA isolation and cDNA construction between samples were corrected using $\beta$-glucoronidase as an internal control for each sample (Breathnach et al. 2006). Relative differences in cytokine mRNA expression resulting from exercise were determined by relative quantification. Relative quantification provides accurate comparison between the initial levels of target cDNA in a sample without requiring that 
the exact copy number be determined (Livak and Schmittgen 2001). The pre-exercise samples were selected as the calibrator and the change in cytokine gene expression post expression relative to the calibrator was then determined for each sample.

\section{Statistical analysis:}

Graphed results are expressed as means +/- standard error of the mean (SEM). For comparison by group and time a two-way ANOVA for repeated measures was used with the a priori level of statistical significance set at $\mathrm{P}<0.10$. For comparison by treatment group alone, such as in the case of the exercise performance endpoints, a paired, 1-tailed Student's t-test was used, with the null hypothesis rejected if $\mathrm{P}<0.10$. This p-value was chosen to reduce type-II error. Post hoc differences were determined using the Tukey test, and correlation coefficients were derived using the Pearson product moment (Sigma Stat 2.0; SPSS Inc., Chicago, IL).

\section{$\underline{\text { Results }}$}

\section{Pharmacokinetics:}

The standard curves created to quantify quercetin presence in plasma and muscle were very linear: $\mathrm{R}^{2}=0.9979$ for plasma (fig. 1) and 0.9998 for muscle (fig. 2). In these graphs the $\mathrm{X}$-axis represents the amount of quercetin added to the control sample, and the $\mathrm{Y}$-axis represents the ratio of quercetin to fisetin detected by the HPLC. This allowed for accurate calculation of quercetin presence in the test samples (fig. $3 \& 4$ ). Plasma quercetin concentration increased after dosing, peaking at $1-2$ hours and returning to baseline levels by 4 hours. Muscle quercetin levels also peaked at about 2 hours, but did not return to baseline levels until 12 hour post-dose. 


\section{Pharmacodynamics}

Performance and respiratory markers:

There was no difference between the quercetin and control groups in readings of maximal oxygen uptake (fig. 5) or respiratory exchange ratio (fig. 6). There was a small $(\sim 5 \%)$ but significant $(\mathrm{P}=0.06)$ increase in run time when the horses were dosed with quercetin (fig. 7). Recovery time is defined as the period following the conclusion of exercise during which the oxygen debt is repaid, and is also known as the alactic or fast phase of recovery. When the horses received quercetin their recovery time shortened significantly ( $\mathrm{P}=0.02)$ compared to their water-dosed trials (fig. 8).

\section{Blood chemistry:}

While hematocrit (fig. 9) and total protein (fig. 10) levels rose significantly in correlation with exercise intensity ( $\mathrm{P}<0.001$ for both measurements), there was no difference between treatment groups $(\mathrm{P}=0.70$ and $\mathrm{P}=0.61$, respectively). Plasma lactate levels showed a marked increase in relation to exercise intensity, peaking 2 min after exercise completion (fig. 11). This increase was independent of treatment. Glucose levels increased slightly during exercise, and rose sharply 2 min after exercise completion (fig. 12). Insulin concentration began to rise following completion of exercise, although large error bars precludes statistical significance (fig. 13). Neither glucose nor insulin showed a response to quercetin. Plasma levels of sodium, (fig. 14), chloride (fig. 15), and potassium (fig. 16) all rose during exercise, returning to baseline levels $30-60$ min later. Plasma calcium levels remained unchanged during the experiment (fig. 17). None of the measured electrolytes were affected by quercetin dosing. 


\section{Cytokines:}

IL-1 mRNA increased slightly until 1 hour after exercise; it then peaked $2-4$ hours after test completion (fig. 18). There was no significant effect from quercetin dosing. The TNF- $\alpha$ mRNA level increased immediately following exercise, returning to baseline levels after 1 hour. It then rose again, peaking at 4 hours and remaining elevated though 24 hours (fig. 19). These increases were neither significant nor related to treatment. The concentration of IL-6 mRNA became slightly elevated $1-4$ hours postexercise (fig. 20), but like IL-1 there was no significant increase and no effect from the drug. IFN- $\gamma$ mRNA levels tripled 2 min after the end of exercise, then fell gradually and remained somewhat elevated through 24 hours (fig. 21). Quercetin may have increased the speed of the decline, but not significantly so. Lastly, GrB levels increased significantly immediately following exercise, and fell gradually over the next two hours (fig. 22). Quercetin had a small but significant effect, lowering GrB levels at all time points.

Muscle cytokines:

Muscle IL-1 mRNA content (fig. 23) increased significantly 1 hour after cessation of exercise in water treated horses. When the horses were treated with quercetin, the increase was delayed until 2 hours post-exercise and rose only half as much as in the water cohort, but this was not statistically significant. Muscle GrB levels (fig. 24) rose significantly 1 hour after exercise, but there was no effect of quercetin. Levels of TNF- $\alpha$, IL-6, and IFN- $\gamma$ mRNA were below the threshold of detection for the test. 


\section{$\underline{\text { Discussion }}$}

\section{Pharmacokinetics}

This study demonstrated that $\sim 12 \mathrm{mpk}$ of quercetin BID can result in measurable levels of the compound in both plasma and muscle. There did not, however, appear to be any benefit from multi-day BID dosing. The relatively quick clearance of quercetin from both plasma and muscle indicates that dosing every 12 hours is insufficient to maintain elevated concentrations. The highest plasma quercetin concentration achieved in this experiment was $727 \mathrm{nM}$, considerably less than the $25-100 \mu \mathrm{M}$ used in most in vitro experiments showing an effect of quercetin on cytokine levels (Comalada et al., 2006; Kempuraj et al., 2006; Nair et al., 2006; Kaneko et al., 2008; Okoko and Oruambo, 2009).

\section{Pharmacodynamics}

Exercise and aerobic performance:

The fast phase of the $\mathrm{VO}_{2}$ recovery curve involves repayment of the oxygen debt and typically occurs within the first 2 minutes following exercise (Margaria et al., 1933; Piper and Spiller, 1970). We found that when pre-treated with quercetin as opposed to water, the length of the horses' fast phase recovery was shortened by about $20 \%$. While this may indicate a potential for decreased time between intensive bouts of exercise, the lack of a quercetin effect on plasma lactate levels could counter this.

Horses were also able to run significantly longer when dosed with quercetin. Only one of the six horses failed to increase its run time; the others increased by $6.9 \pm 2.3 \%$. A recent study using quercetin dosing in healthy-but-untrained humans also showed a 
substantial 13.2\% increase in time to exercise fatigue (Davis et al., 2010). As ours was a graded exercise test, the strenuousness of the exercise was increased in a stepwise fashion. This caused a clustering of the run time data at the later, higher speeds and likely reduced the amplitude of the quercetin effect. A similar test wherein horses run until exhaustion at a constant speed may give more precise and representative results. Cytokines:

Several factors including type, intensity, and duration of physical work have been shown to influence the effect of exercise on cytokine levels in humans (Bruunsgaard et al., 1997; Ostrowski et al., 1998a, b; Ostrowski et al., 1999; Moldoveanu et al., 2000; Kimura et al., 2001). This effect, however, is not straightforward. For instance, while some experimenters found TNF- $\alpha$ to increase following exercise (Espersen et al., 1990; Moldoveanu et al., 2000), others found no such increase (Rivier et al., 1994; Ullum et al., 1994; Ostrowski et al., 1998a, b). The same discrepancy can be found in studies measuring concentrations of IL-1, with some studies showing increases (Cannon et al., 1986; Evans et al., 1986) and others showing no change (Ulum et al., 1994; Ostrowski et al., 1998a, b). In a review paper, Pedersen et al. (1998) postulated that these differences are likely due, at least in part, to intensity, type, and duration of the exercise. In the case of IL-6, Brunnsgaard et al. (1997) demonstrated that eccentric-type exercise was much more likely to cause a detectable IL-6 increase than was concentric exercise, and a recent review (Pedersen and Febbraio, 2008) offered convincing evidence that IL-6 levels do not rise significantly unless aerobic exercise, such as bicycling or running, is performed for at least $30-60$ minutes. As the horses in our experiment only ran 5-7 minutes, this may explain why we did not see a significant rise in blood IL-6 levels. 
Another cause for discrepancy is the method used for measuring cytokine levels, typically either polymerase chain reaction (PCR) or enzyme-linked immunosorbent assay (ELISA). PCR indirectly measures gene expression, and is therefore useful for determining up- or down-regulation of mRNA for specific proteins. ELISA, on the other hand, directly measures the levels of the protein. Several cytokines, including IL-1 and TNF- $\alpha$, are stored in the cytosol in an inactive form, and are released only when cleaved by a protease (Hazuda et al., 1990; Cerretti et al., 1992; Thornberry et al., 1992). In this case, we would not expect to see up-regulation of IL-1 or TNF- $\alpha$ mRNA until the levels in the cytosol were sufficiently depleted. As we used the PCR method of detection, it is therefore unsurprising that we did not see significant exercise-induced increases in blood IL-1 or TNF- $\alpha$ gene expression until $2-4$ hours after exercise. In support of this hypothesis, one study found that while $3 \mathrm{~h}$ of moderate-intensity exercise elevated blood concentrations of IL-1 1 , IL- 6 , and TNF- $\alpha$ as measured by ELISA, it had no effect on their mRNA levels in peripheral blood mononuclear cells as measured via PCR (Moldoveanu et al., 2000). Since both IFN- $\gamma$ and GrB proteins are produced rapidly in response to an immune challenge, an increase in their corresponding mRNA concentration immediately following exercise is to be expected.

GrB is a serine protease released from cytotoxic lymphocytes (Berke, 1995a, b), and its primary function is to induce apoptosis in infected target cells (Shi et al., 1992; Smyth and Trapani, 1995; Froelich et al., 1998). While there is a paucity of information in the literature directly linking GrB and exercise, a simple indirect link is easily established. GrB levels increase dramatically in vivo in response to a bolus lipopolysaccharide (LPS) injection (Lauw et al., 2000). It has been well documented that 
LPS levels rise in response to strenuous exercise in humans (Bosenberg et al., 1988;

Brocke-Utne et al., 1988; Camus et al., 1997; Jeukendrup et al., 2000), including following a GXT (Ashton et al., 2003). Our measurement of increased GrB blood levels following exercise is therefore consistent with previous experimentation.

Lauw et al. (2000) also demonstrated that anti-TNF monoclonal antibodies (mAbs) significantly reduced the LPS-induced increase in GrB, suggesting that TNF- $\alpha$ is at least in part responsible for GrB release. Transcription of the TNF- $\alpha$ gene is induced by nuclear factor- $\kappa \mathrm{B}(\mathrm{NF}-\kappa \mathrm{B})$ (Manning and Anderson, 1994; Baldwin, 1996; Baeuerle and Baichwal, 1997). NF-אB normally exists in the cytosol as a heterodimer complexed with the inhibitory protein I BB. External stimuli, such as inflammatory cytokines, bacterial or viral antigens, and LPS activate receptors on the cell surface. This begins a cascade in which protein kinase $\mathrm{C}(\mathrm{PKC})$ ultimately phosphorolates $\mathrm{I} \kappa \mathrm{B}$, causing its degradation by proteasomes. In vitro studies have shown that in both rodent- and humanderived cells, quercetin inhibits the phosphorylation and degradation of IкB (Comalada et al., 2005; Comalada et al., 2006; Nair et al., 2006; Kaneko et al., 2008; Ying et al., 2009). While in theory this sequence could explain our observation of a significant decrease in blood GrB in quercetin-treated horses, the lack of a quercetin effect on blood TNF- $\alpha$ mRNA levels is in conflict with this assumption, as is an experiment in humans that demonstrated no effect of quercetin on ELISA measurements of muscle NF- $\mathrm{BB}$ following exercise (Nieman et al., 2007).

GrB has been shown to be locally elevated in BAL fluid in patients with chronic allergic asthma (Bratke et al., 2004) and hypersensitive pneumonitis (Tremblay et al., 2000). Assuming that quercetin is able to reduce GrB levels, via disruption of the NF- $\kappa \mathrm{B}$ 
pathway or some other method, it could conceivably decrease apoptosis in lung tissue.

This may be partially responsible for the decrease in recovery time observed in this study. 


\section{Chapter 3: Conclusion}

Acute exhaustive exercise such as a GXT results in significant increases in mRNA transcription of IL-1, TNF- $\alpha$, IFN- $\gamma$, and GrB in the blood, and of IL- 1 and GrB in the muscle. Blood levels of IL-6 mRNA were not affected, and muscle levels of TNF- $\alpha$ and IFN- $\gamma$ were below the level of detection. Multi-day BID administration of quercetin $(6 \mathrm{~g}, \sim 12 \mathrm{mpk})$ significantly reduced the level of GrB mRNA in the blood following exercise, but had no effect on the other cytokines. This lack of a quercetin effect is consistent with data from human trials (Nieman et al., 2007). When dosed with quercetin the horses were able to run significantly longer (also consistent with human trials: Davis et al., 2010), and took significantly less time to recover following exercise. Maximal oxygen uptake and respiratory exchange ratio were not affected by dosing.

This study provides compelling evidence that quercetin could be useful in enhancing exercise performance, although the mechanism for this enhancement is unclear. Using a higher dosage of quercetin, such that its plasma concentration is more in line with effective in vitro levels, could provide a clearer picture. In addition, using an ELISA test to determine protein levels could give a more accurate representation of circulating cytokine levels. As quercetin's method of action is suspected to involve inhibition of cytokine gene transcription, PCR would still be useful in detecting any down-regulation.

If quercetin is consistently demonstrated to increase performance and decrease soreness it would be a boon to anyone who's work or lifestyle demands strenuous activity, including soldiers and athletes of any species. Assuming that its method of action is to disrupt transcription of inflammation-inducing cytokine genes via the NF- $\kappa \mathrm{B}$ 
pathway, it would avoid most, if not all, of the negative side effects associated with NSAID use. While this study alone is not sufficient to recommend quercetin for mainstream usage, it adds to a growing body of literature supporting the drug's effectiveness. 


\section{$\underline{\text { References }}$}

114.Ashton, T., Young, I.S., Davison, G.W., Rowlands, C.C., McEneny, J., Van Blerk, C., Jones, E., Peters, J.R., Jackson, S.K., 2003. Exercise-induced endotoxemia: the effect of ascorbic acid supplementation. Free Radical Biology and Medicine 35, 284291

115.Baeuerle, P., Baichwal, V., 1997. NF- $\kappa$ B as a frequent target for immunosuppressive and anti-inflammatory molecules. Advances in Immunology 65, 111-137

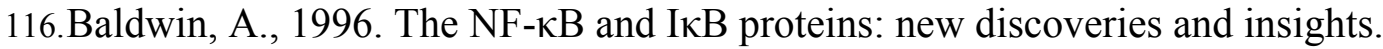
Annual Review of Immunology 14: 141-179

117.Berke, G., 1995a. The CTL's kiss of death. Cell 81, 9-12

118.Berke, G., 1995b. Unlocking the secrets of CTL and NK cells. Immunology Today $16,343-346$

119.Bertrand, V., Guimbaud, R., Tulliez, M., Mauprivez, C., Sogni, P., Couturier, D., Giroud, J., Chaussade, S., Chauvelot-Moachon, L., 1998. Increase in tumor necrosis factor- $\alpha$ production linked to the toxicity of indomethacin for the rat small intestine. British Journal of Pharmacology 124, 1385-1394

120.Bosenberg, A.T., Brock-Utne, J.G., Gaffin, S.L., Wells, M.T B., Blake, G. T. W., 1988. Strenuous exercise causes systemic endotoxaemia. Journal of Applied Physiology 65, 106-108

121.Bratke, K., Bottcher, B., Leeder, K., Schmidt, S., Kupper, M., Virchow, J.C. Jr., Luttmann, W., 2004. Increase in granzyme B lymphocytes and soluble granzyme B in bronchoalveolar lavage of allergen challenged patients with atopic asthma. Clinical and Experimental Immunology 136, 542-548

122.Breathnach, C.C., Sturgill-Wright, T., Stiltner, J.L., Adams, A.A., Lunn, D.P., Horohov, D.W., 2006. Foals are interferon gamma-deficient at birth. Veterinary Immunology and Immunopatholology 112, 199-209

123.Brock-Utne, J.G., Gaffin, S.L., Wells, M.T., Gathiram, P., Sohar, E., James, M.F., Morrell, D.F., Norman, R.J., 1988. Endotoxaemia in exhausted runners after a long distance race. South African Medical Journal 73533-73536

124.Bruunsgaard, H., Galbo, H., Halkjaer-Kristensen, J., Johansen, T., MacLean, D., Pedersen, B.K., 1997. Exercise-induced increase in serum interleukin-6 in humans is related to muscle damage. Journal of Physiology 499, 833-841 
125.Camus, G., Poortmans, J., Nys, M., Deby-Dupont, G., Duchateau, J., Deby, C., Lamy, M., 1997. Mild endotoxaemia and the inflammatory response induced by a marathon race. Clinical Science 92, 415-422

126.Camussi, G., Lupia, E., 1998. The future role of anti-tumour necrosis factor (TNF) products in the treatment of rheumatoid arthritis. Drugs 55, 613-620

127.Cannon, J.G., Evans, W.J., Hughes, V.A., Meredith, C.N., Dinarello, C.A., 1986. Physiological mechanisms contributing to increased IL-1 secretion. Journal of Applied Physiology 61, 1869-1874

128.Cerretti, D., Kozlosky, C., Mosley, B., Nelson, N., Van Ness, K., Greenstreet, T., March, C., Kronheim, S., Druck, T., Cannizzaro, L., Huebner, K., Black, R., 1992. Molecular cloning of the IL-1ß processing enzyme. Science 256, 97-100

129.Chen, X., Yin, O., Zuo, Z., Chow, M., 2005. Pharmacokinteics and modeling of quercetin and metabolites. Pharmaceutical Research 22, 892-901

130.Comalada, M., Camuesco, D., Sierra, S., Ballester, I., Xaus, J., Gálvez, J., Zarzualo, A., 2005, In vivo quercitrin anti-inflammatory effect involves release of quercetin, which inhibits inflammation through down-regulation of the NK- $\kappa$ B pathway. European Journal of Immunology 35, 584-592

131.Comalada, M., Ballester, I., Bailón, E., Sierra, S., Xaus, J., Gálvez, J., Sánchez de Madina, F., Zarzualo, A., 2006. Inhibition of pro-inflammatory markers in primary bone marrow-derived mouse macrophages by naturally occurring flavonoids: Analyss of the structure-activity relationship. Biochemical Pharmacology 72, 1010-1021

132.Davis, J., Carlstedt, C., Chen, S., Carmichael, M., Murphy, E., 2010. The dietary flavonoid quercetin increases $\mathrm{VO}_{2}$ max and endurance capacity. International Journal of Sport Nutrition and Exercise Metabolism 20, 56-62

133.de Boer, V., Dihal, A., van der Woude, H., Arts, I., Wolffram, S., Alink, G., Rietjens, I., Keijer, J., Hollman, P., 2005. Tissue distribution of quercetin in rats and pigs. Journal of Nutrition 135, 1718-1725

134.Endres, S., Whitaker, R., Ghorbani, R., Meydani, S., Dinarello, C., 1996. Oral aspirin and ibuprofen increase cytokine-induced systhesis of IL-1ß and of tumour necrosis factor- $\alpha$ ex vivo. Immunology 87, 264-270

135.Erlund, I., Alrthan, G., Siren, H., Ariniemi, K., Aro, A., 1999. Validated method for the quantization of quercetin from human plasma using high-performance liquid chromatography with electrochemical detection. Journal of Chromatography B 727, 179-189 
136.Espersen, G.T., Elback, A., Ernst, E., Toft, E., Kaalund, S., Jersild, C., Grunnet, N., 1990. Effect of physical exercise on cytokines and lymphocyte subpopulations in human peripheral blood. Acta Pathologica, Microbiologica et Immunologica Scandinavica 98, 395-400

137.Evans, W.J., Meredith, C.N., Cannon, J.G., Dinarello, C.A., Frontera, W.R., Hughes, V.A., Jones, B.H., Knuttgen, H.G., 1986. Metabolic changes following eccentric exercise in trained and untrained men. Journal of Applied Physiology 61, 1864-1868

138.Froelich, C., Dixit, V., Yang, X., 1998. Lymphocyte granule-mediated apoptosis: matters of viral mimicry and deadly proteases. Immunology Today 19, 30-36

139.González-Segovia, R., Quintanar, J., Salinas, E., Ceballos-Salazar, R., AvilesJiménez, F., Torres-López, J., 2008. Effect of the flavonoid quercetin on inflammation and lipid peroxidation induced by Helicobacter pylori in gastric mucosa of guinea pig. Journal of Gastroenterology 43, 441-447

140.Hazuda, D., Strickler, J., Kueppers, F., Simon, P., Young, P., 1990. Processing of precursor interleukin-1 beta and inflammatory disease. Journal of Biological Chemistry 265, 6318-6322

141.Jeukendrup, A.E., Vet-Joop, K., Sturk, A., Stegen, J.H., Senden, J., Saris, W.H., Wagenmakers, A.J., 2000. Relationship between gastrointestinal complaints and endotoxaemia, cytokine release and the acute phase reaction during and after a long distance triathlon in highly trained men. Clinical Science 98, 47-55

142.Kaneko, M., Takimoto, H., Sugiyama, T., Seki, Y., Kawaguchi, K., Kumazawa, Y., 2008. Suppressive effects of the flavonoids quercetin and luteolin on the accumulation of lipid rafts after signal transduction via receptors. Immunopharmacology and Immunotoxicology 30, 867-882

143.Kempuraj, D., Castellani, M., Petrarca, C., Conti, P., Theoharides, T., Vecchiet, J., 2006. Inhibitory effect of quercetin on tryptase and interleukin-6 release, and histamine decarboxylase mRNA transcription by human mast cell-1 cell line. Clinical and Experimental Medicine 6, 150-156

144.Kimura, H., Suzui, M., Nagao, F., Matsumoto, K., 2001. Highly sensitive determination of plasma cytokines by time-resolved fluroimmunoassay; Effect of bicycle exercise on plasma level of interleukin-1alpha (IL-1alpha), Tumor necrosis factor alpha (TNF-alpha), and Interferon Gamma (IFN gamma). Analytical Sciences $17,593-597$

145.Lauw, F.N., Simpson, A.J.H., Hack, C.E., Prins, J.M., Wolbink, A.M., van Deventer, S.J.H., Chaowagul, W., White, N.J., van der Poll, T., 2000. Soluble granzymes are released during human endotoxemia and in patients with severe infection due to gram-negative bacteria. Journal of Infectious Diseases 182, 206-213 
146.Livak, K.J., Schmittgen, T.D., 2001. Analysis of Relative Gene Expression Data Using Real-Time Quantitative PCR and the $2^{-\Delta \Delta C}$ Method. Methods 25, 402-408

147.Manning, A., Anderson, D., 1994. Transcription factor NF- $\kappa$ B: an emerging regulator or inflammation. Annual Reports in Medicinal Chemistry 29, 235-244

148.Margaria, R., Edwards, H., Dill, D., 1933. The possible mechanisms of contracting and paying the oxygen debt and the role of lactic acid in muscular contraction. American Journal of Physiology 106, 689-715

149.McKeever, K., Schurg, W., Convertino, V., 1988. A modified Evans blue dye method for determining plasma volume in the horse. Journal of Equine Veterinary Science 8, 208-212

150.Moldoveanu, A., Shephard, R., Shek, P., 2000. Exercise elevates plasma levels but not gene expression of Il-1Beta, IL-6, and TNF-alpha in blood mononuclear cells. Journal of Applied Physiology 89, 1499-1504

151.Nair, M., Mahajan, S., Reynolds, J., Aalinkeel, R., Nair, H., Schwartz, S., Kandaswami, C., 2006. The flavonoid quercetin inhibits proinflammatory cytokine (tumor necrosis factor alpha) gene expression in normal peripheral blood mononuclear cells via modulation of the NF- $\kappa$ B system. Clinical and Vaccine Immunology 13, 319-328

152.Nieman, D., Henson, D., Davis, J., Murphy, A., Jenkens, D., Gross, S., Carmichael, M., Quindry, J., Dumke, C., Utter, A., McAnulty, S., McAnulty, L., Triplett, N., Mayer, E., 2007. Quercetin's influence on exercise-induced changes in plasma cytokines and muscle and leukocyte cytokine mRNA. Journal of Applied Physiology $103,1728-1735$

153.Okoko, T., Oruambo, I., 2009. Inhibitory activity of quercetin and its metabolite on lipopolysaccharide-induced activation of macrophage U937 cells. Food and Chemical Toxicology 47, 809-812

154.Ostrowski, K., Rhode, T., Zacho, M., Asp, S, Pedersen, B.K., 1998a. Evidence that interleukin-6 is produced in human skeletal muscle during prolonged running. Journal of Physiology 508, 949-953

155.Ostrowski, K., Hermann, C., Bangash, A., Schjerling, P., Nielsen, J., Pedersen, B.K., 1998b. A trauma-like elevation of plasma cytokines in humans in response to treadmill running. Journal of Physiology 513, 889-894

156.Ostrowski, K., Rohde, T., Asp, S., Schjerling, P., Pedersen, B.K., 1999. Pro- and antiinflammatory cytokine balance in strenuous exercise in humans. Journal of Physiology 515, 287-297 
157.Park, H., Lee, C., Jung, I., Lee, J., Jeong, J., Chang, J., Chun, S., Kim, M., Choi., I., Ahn, S., Shin, Y., Yeom, S., Park, Y., 2009. Quercetin regulates Th1/Th2 balance in a murine model of asthma. International Immunopharmacology 9, 261-267

158.Pedersen, B.K., Ostrowski, K., Rohde, T., Bruunsgaard, H., 1998. The cytokine response to exercise. Canadian Journal of Physiology and Pharmacology 76, 505-511

159.Pedersen, B.K., Febbraio, M.A., 2008. Muscle as an endocrine organ: focus on muscle-derived IL-6. Physiological Reviews 88, 1379-1406

160.Piper, J., Spiller, P., 1970. Repayment of $\mathrm{O}_{2}$ debt and resynthesis of high-energy phosphates in gastrocnemius muscle of the dog. Journal of Applied Physiology 20, 657-662

161.Rivier, A., Pene, J., Chanez, P., Anselme, F., Caillaud, C., Prefaut, C., Godard, P., Bousquet, J., 1994. Release of cytokines by blood monocytes during strenuous exercise. International Journal of Sports Medicine 15, 192-198

162.Shi, L., Ka, C., Powers, J., Aebersold, R., Greenberg, A., 1992. Purification of three cytotoxic lymphocyte granule serine proteases that induce apoptosis through distinct substrate and target cell interactions. Journal of Experimental Medicine 176, 15211529

163.Slomiany, B., Piotrowski, J., Slomiany, A., 1997. Induction of tumor necrosis factor$\alpha$ and apoptosis in gastric mucosal injury by indomethacin: effect of omeprazole and ebrotidine. Scandinavian Journal of Gastroenterology 32, 638-642

164.Smyth, M., Trapani, J., 1995. Granzymes: exogenous proteinases that induce target cell apoptosis. Immunology Today 16, 202-206

165.Thornberry, N., Bull, H., Calaycay, J., Chapman, A., Howard, M., Kostura, D., Miller, S., Molineaux, J., Weidner, J., Aunins, J., Elliston, K., Ayala, J., Casano, F., Chin, J., Ding, G., Egger, L., Gaffney, E., Limjuco, G., Palyha, O., Raju, S., Rolando, A., Salley, J., Yamin, T., Lee, T., Shively, J., MacCross, M., Mumford, R., Schmidt, J., Tocci, M., 1992. A novel heterodimeric cysteine protease is required for interleukin-1 beta processing in monocytes. Nature 356, 768-774

166.Tremblay, G.M., Wolbink, A.M., Cormier, Y., Hack, C.E., 2000. Granzyme activity in the inflamed lung is not controlled by endogenous serine proteinase inhibitors. Journal of Immunology 165, 3966-3969.

167.Ullum, H., Haahr, P.M., Diamant, M., Palmo, J., Halkjaer-Kristensen, J., Pedersen, B.K., 1994. Bicycle exercise enhances plasma IL-6 but does not change IL-1 $\alpha$, IL-1ß, IL-6, or TNF- $\alpha$ pre-mRNA in BMNC. Journal of Applied Physiology 77, 93-97 
168. Ying, B., Yang, T., Song, X., Hu, X., Fan, H., Lu, X., Chen, L., Cheng, D., Wang, T., Liu, D., Xu, D., Wei, Y., Wen, F., 2009. Quercetin inhibits IL-1 beta-induced ICAM1 expression in pulmonary epithelial cell line A549 through the MAPK pathways. Molecular Biology Reports 36, 1825-1832 


\section{Figures}

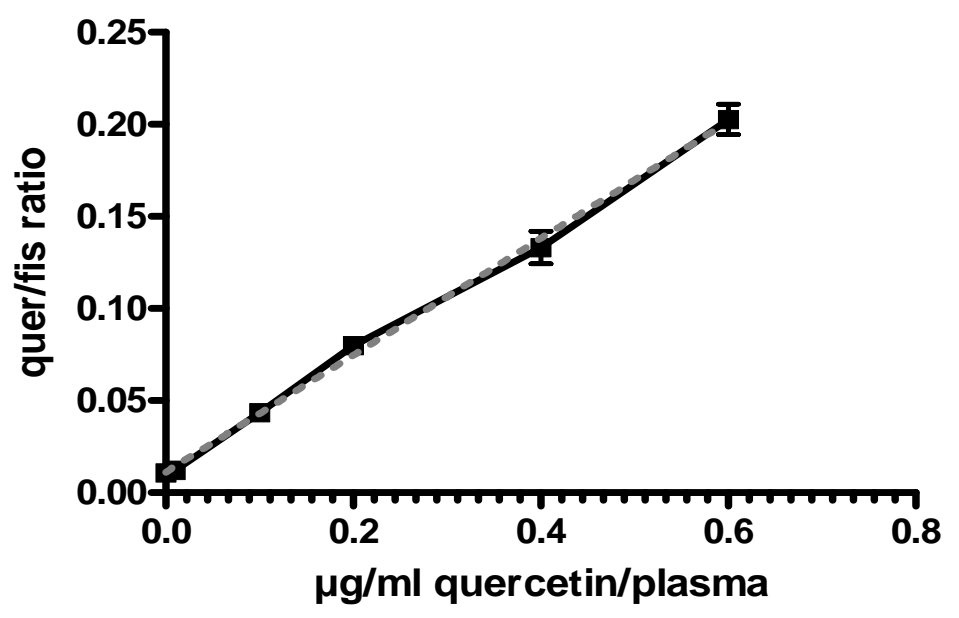

Figure 1: HLPC-measured ratio of quercetin to fisetin vs known concentration of quercetin-spiked plasma samples. $\mathrm{R}^{2}=0.9979$

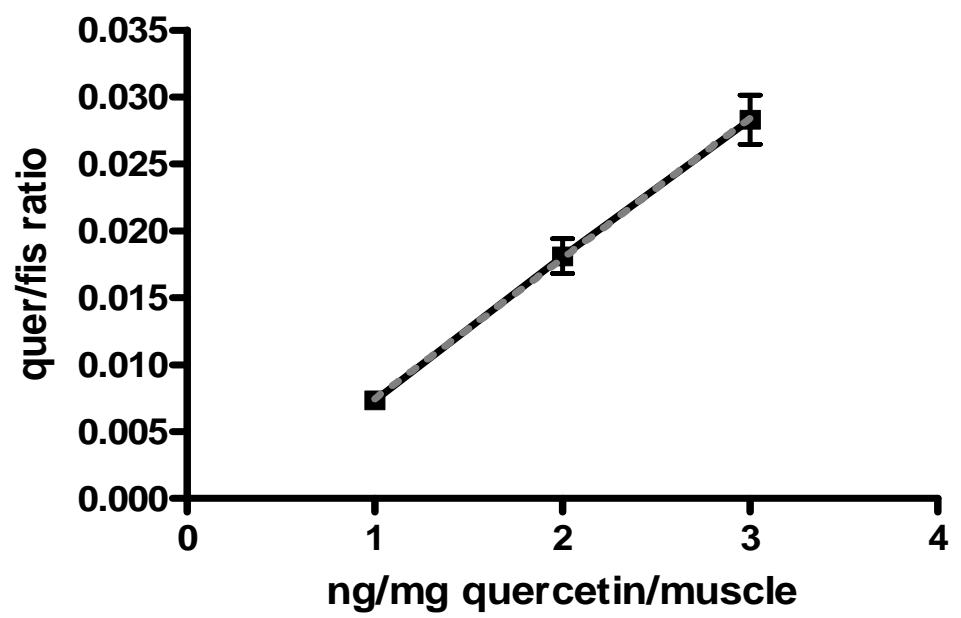

Figure 2: HLPC-measured ratio of quercetin to fisetin vs known concentration of quercetin-spiked muscle samples. $\mathrm{R}^{2}=0.9998$ 


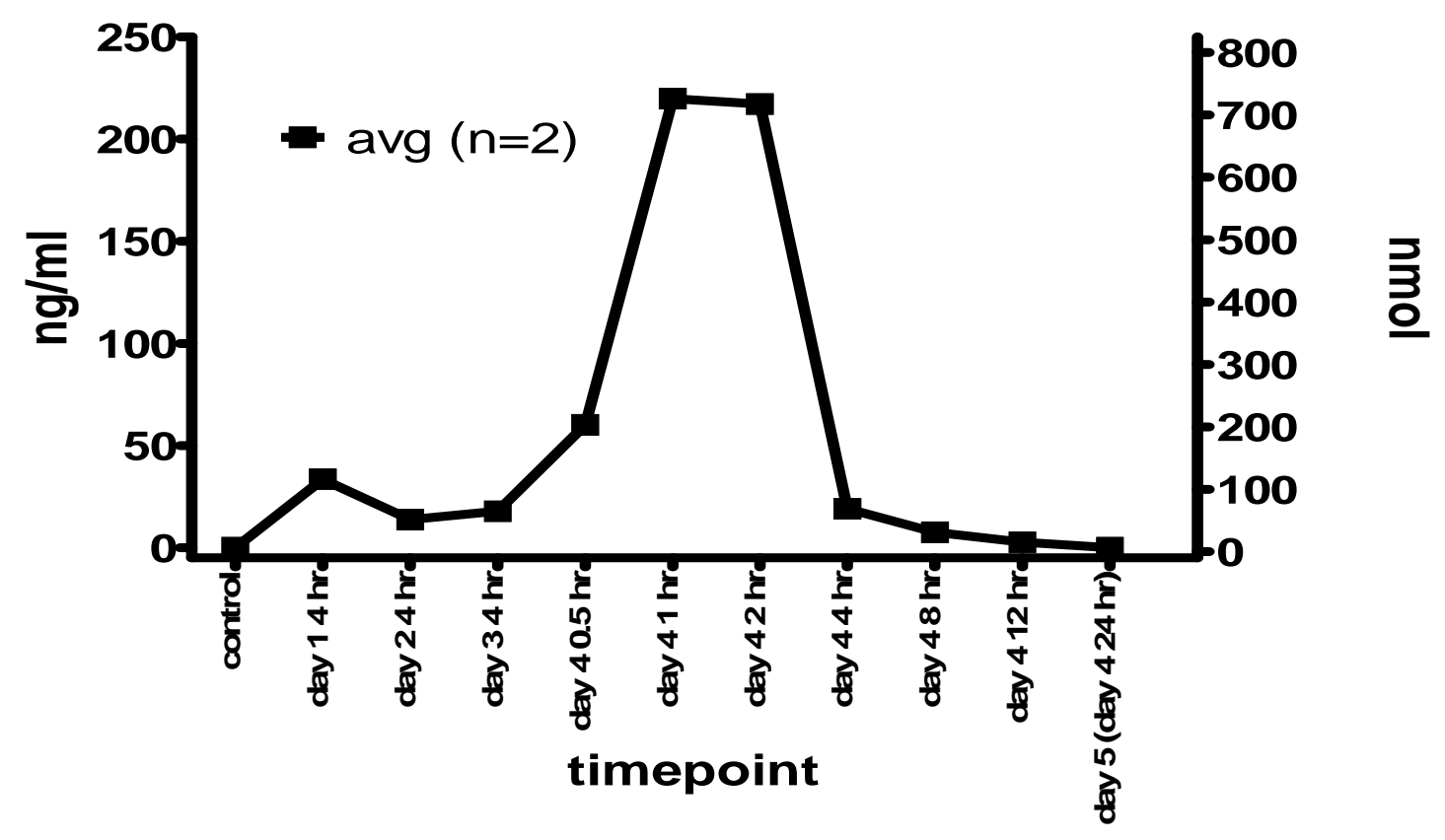

Figure 3: Plasma concentration of quercetin following seven 6g BID oral doses

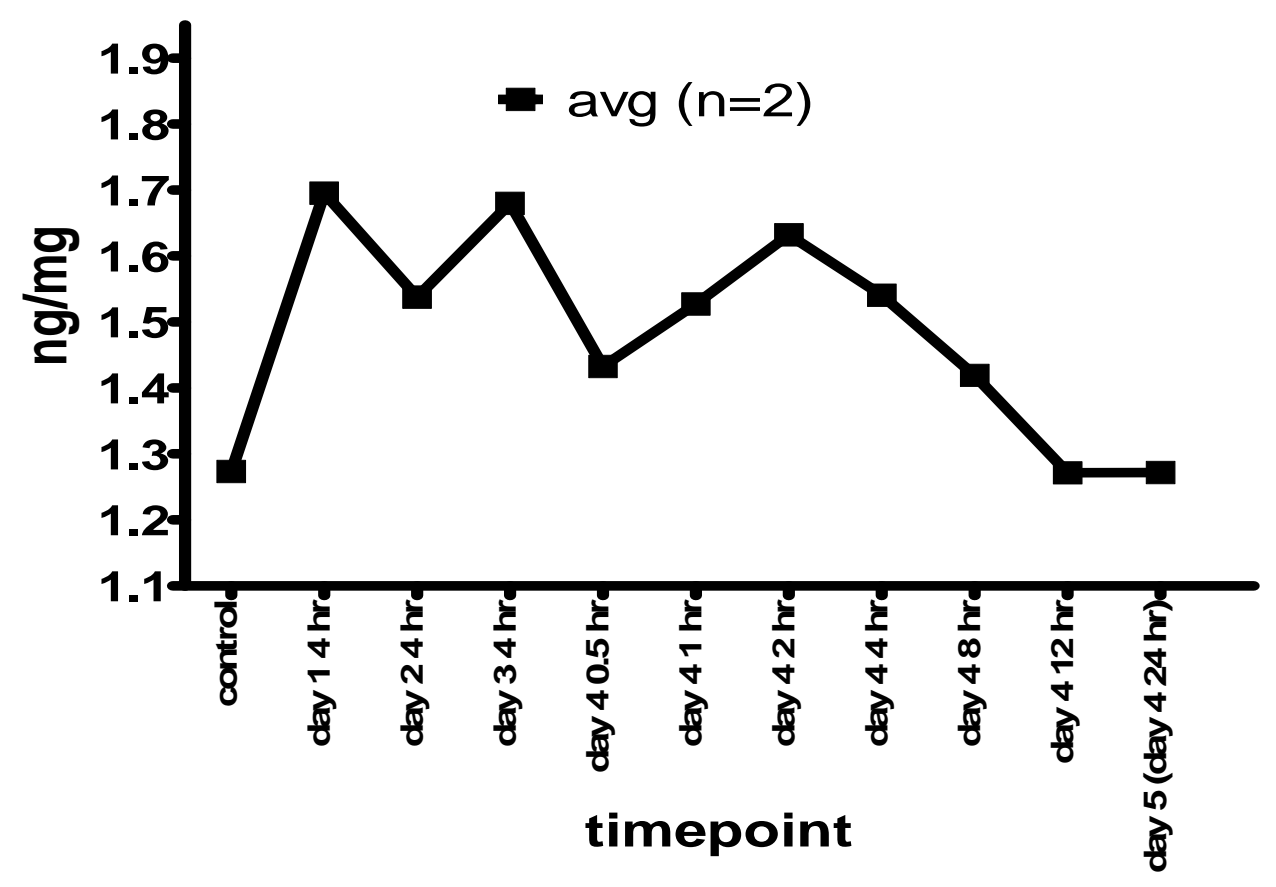

Figure 4: Muscle concentration of quercetin following seven $6 \mathrm{~g}$ BID oral doses. 


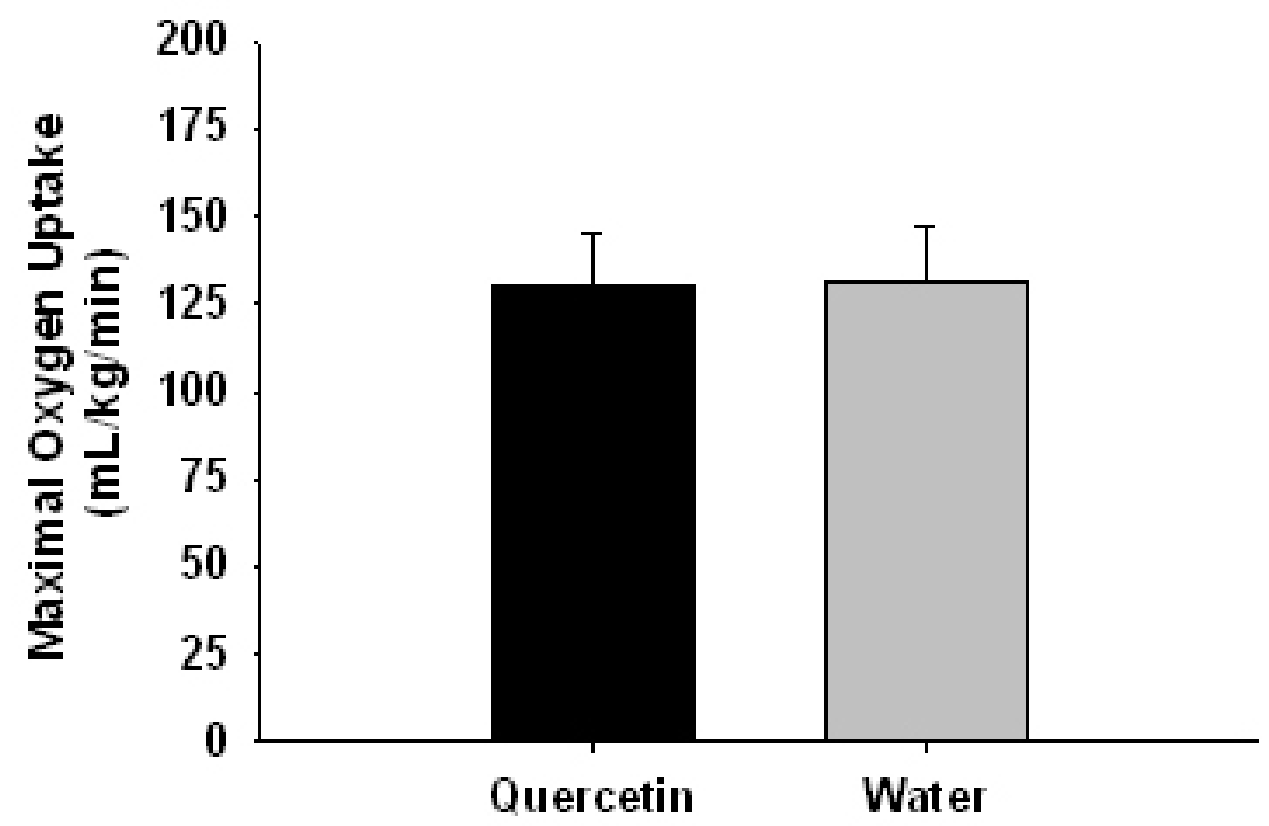

Figure 5: Maximal $\mathrm{O}^{2}$ uptake during the GXT. There was no significant effect of treatment $(\mathrm{P}>0.1)$.

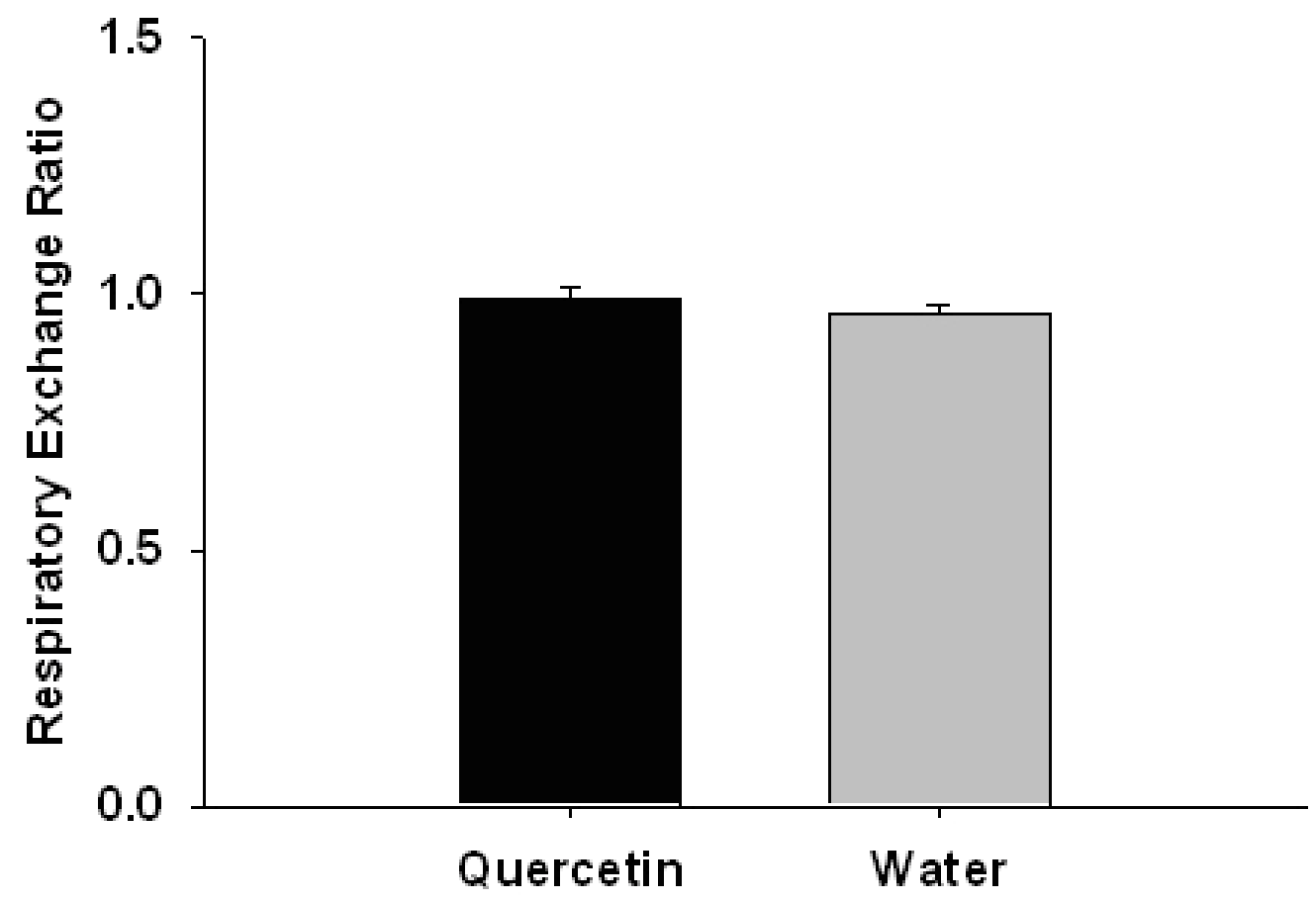

Figure 6: Respiratory exchange ratio during the GXT. There was no significant effect of treatment $(\mathrm{P}>0.1)$. 


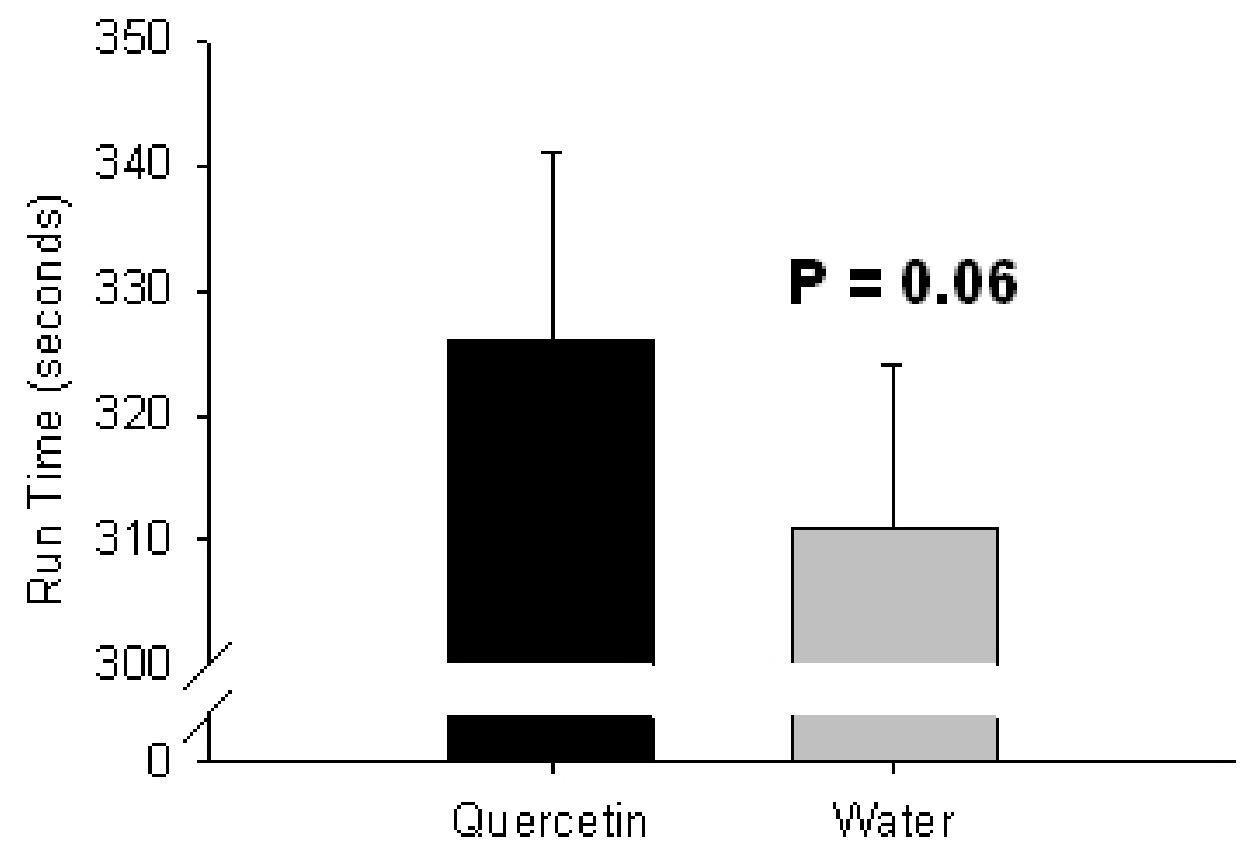

Figure 7: Total run time during the GXT. There a significant $(\mathrm{P}=0.06)$ difference between treatments.

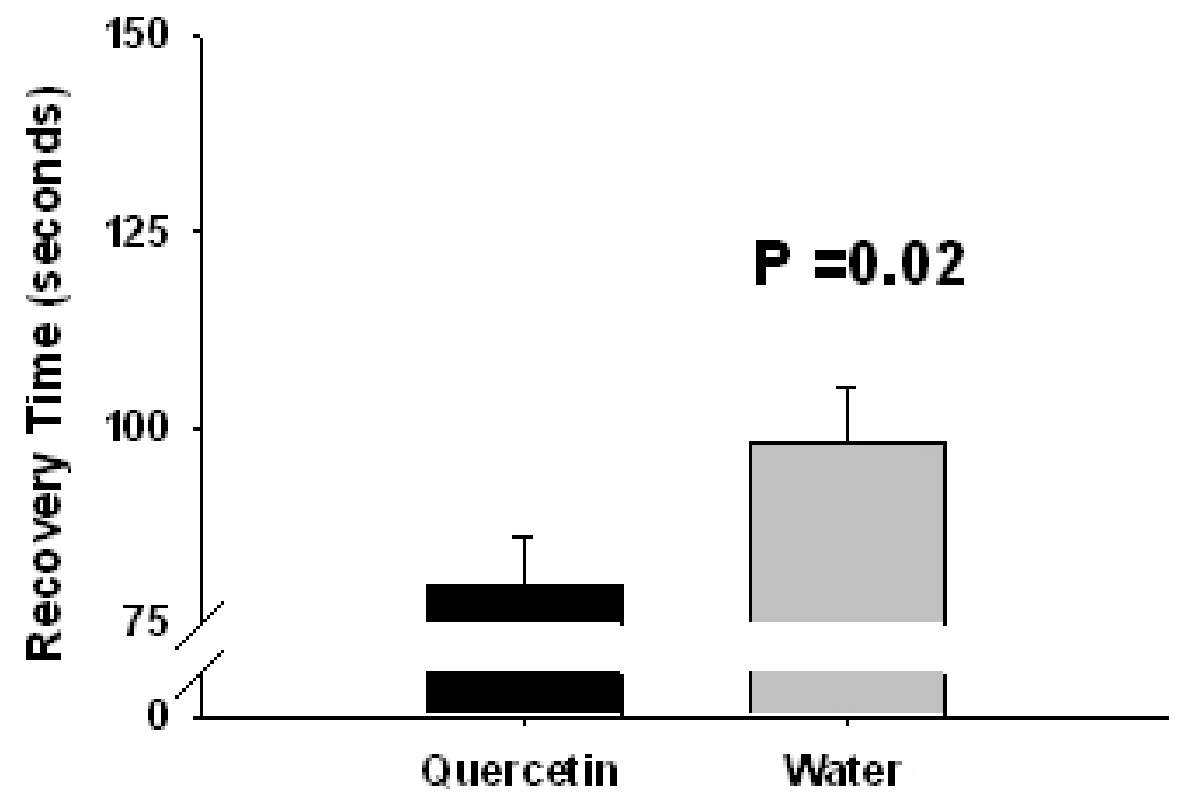

Figure 8: Recovery time (alactic phase) following the GXT. There a significant $(\mathrm{P}=0.02)$ difference between treatments. 


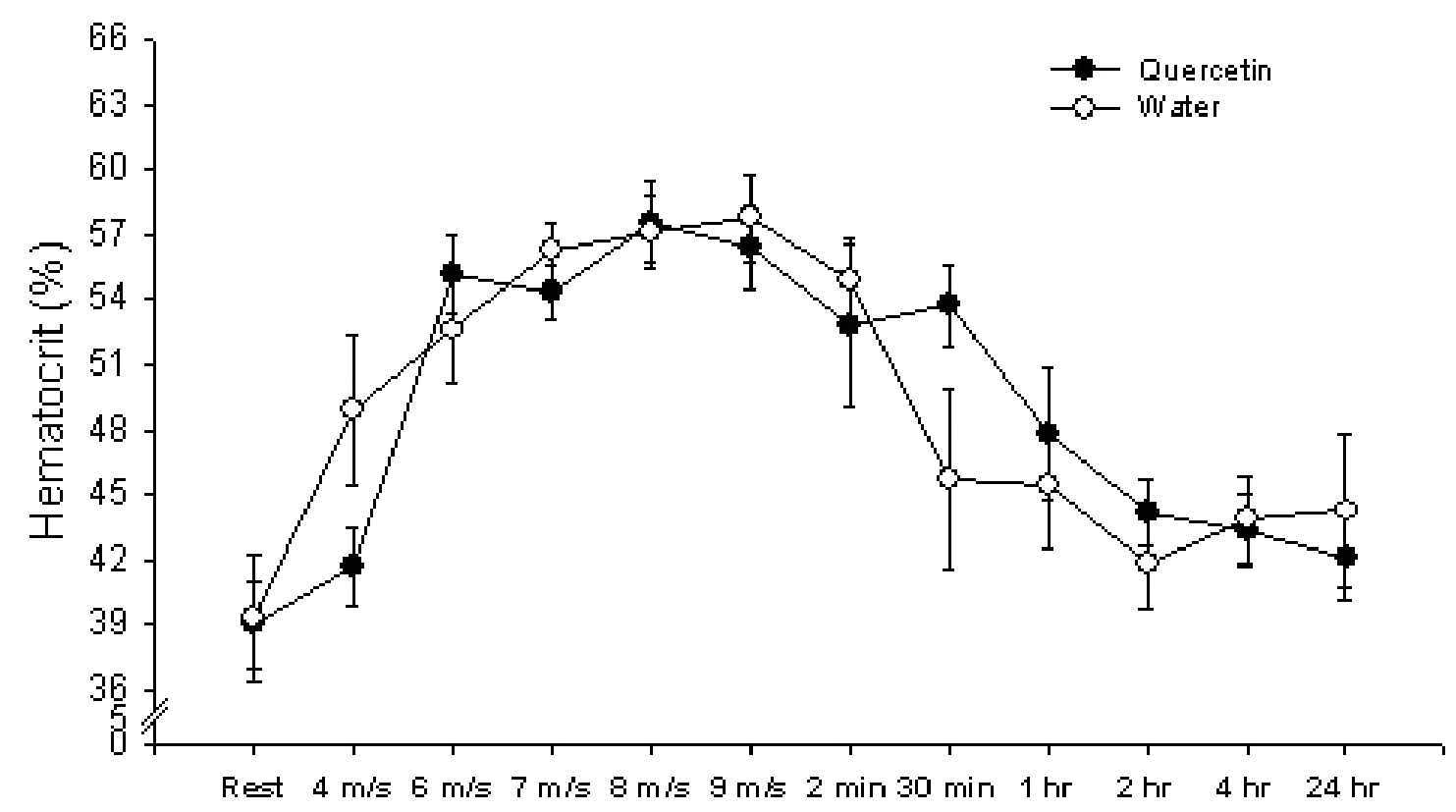

Figure 9: Hematatocrit levels before, during, and following the GXT. There is a significant effect of exercise $(\mathrm{P}<0.001)$, but no effect of treatment $(\mathrm{P}>0.1)$.

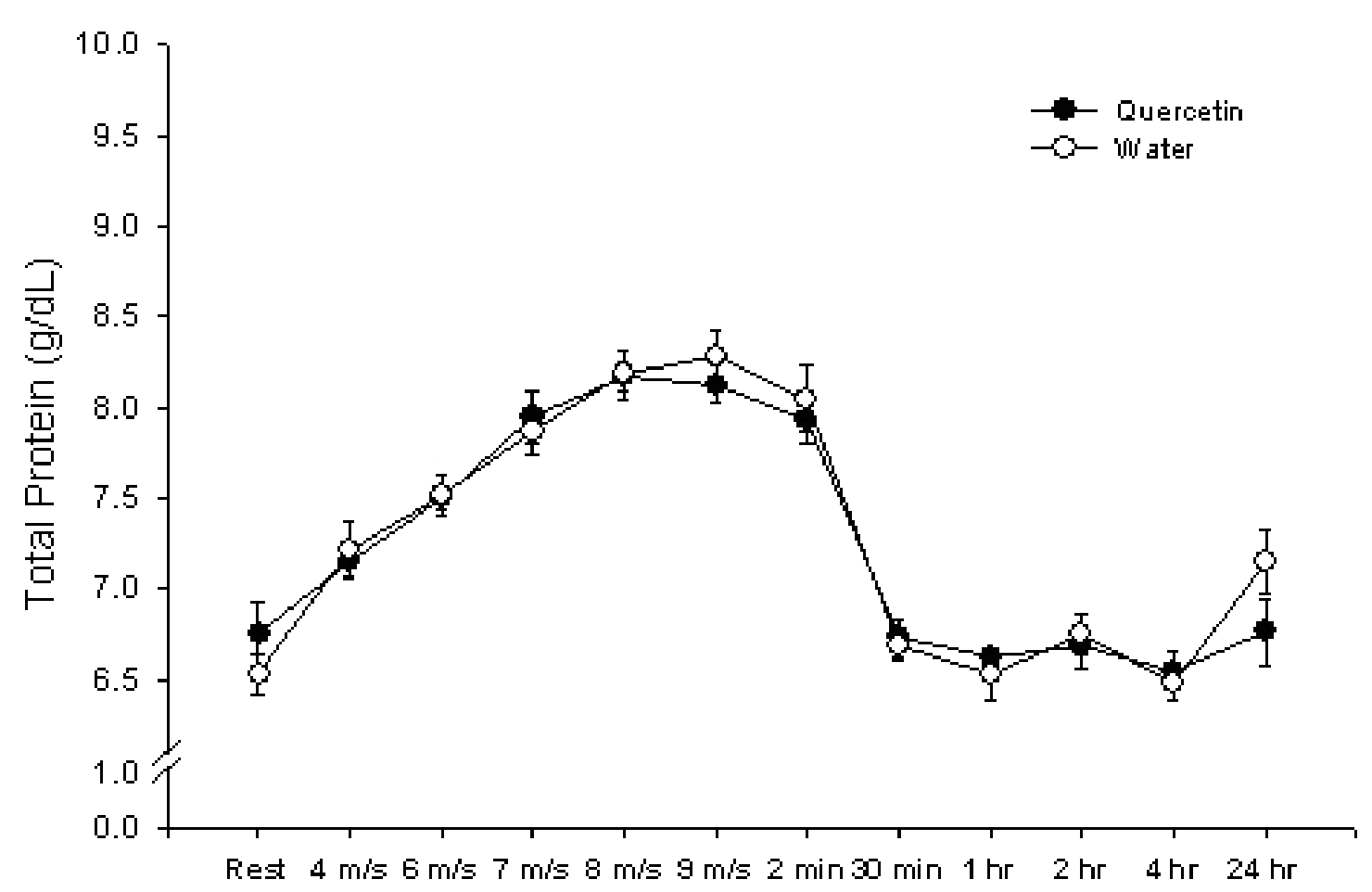

Figure 10: Total protein levels before, during, and following the GXT. There is a significant effect of exercise $(\mathrm{P}<0.001)$, but no effect of treatment $(\mathrm{P}>0.1)$. 


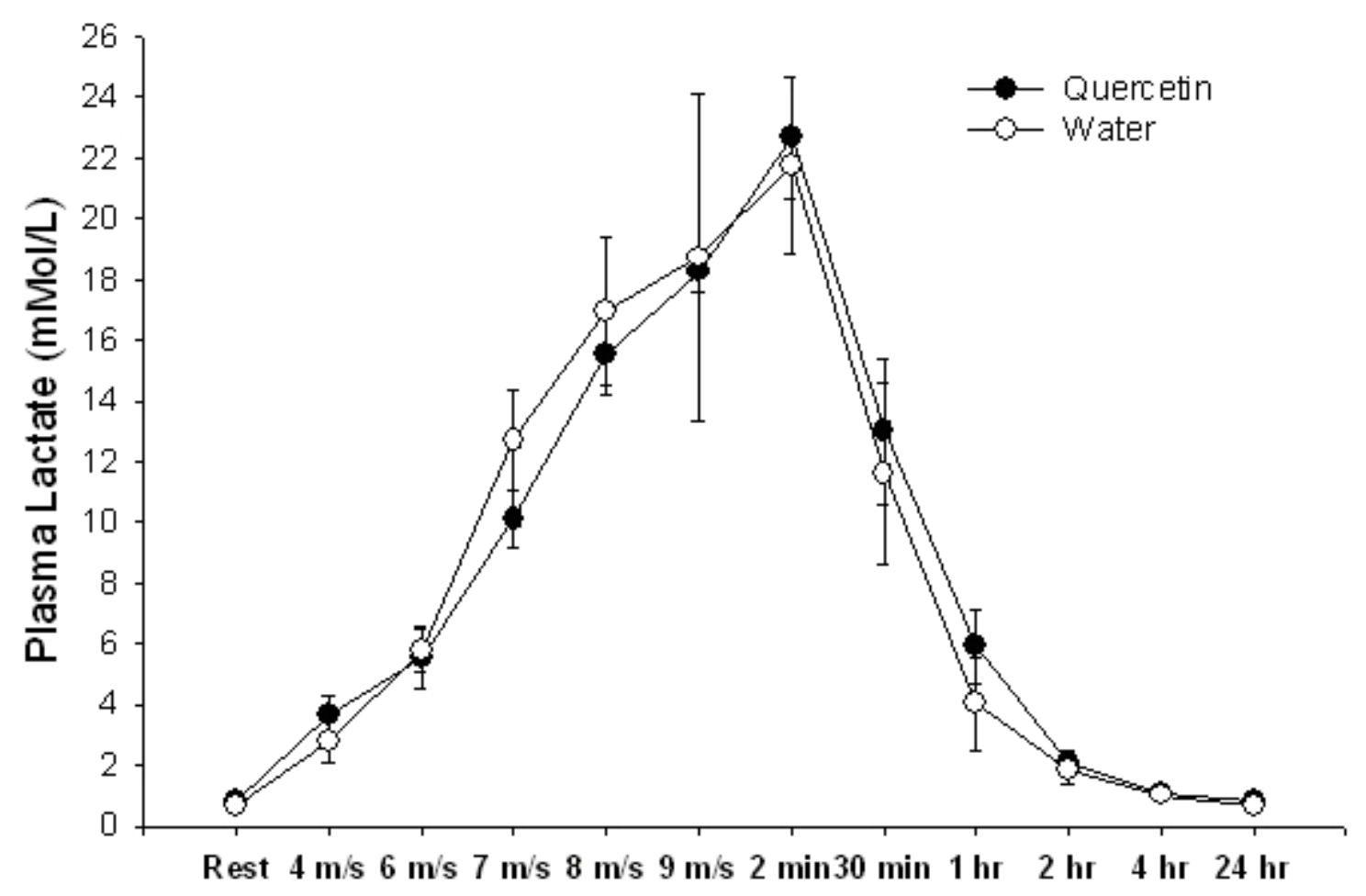

Figure 11: Plasma lactate levels before, during, and following the GXT. There is a significant effect of exercise $(\mathrm{P}<0.1)$, but no effect of treatment $(\mathrm{P}>0.1)$.

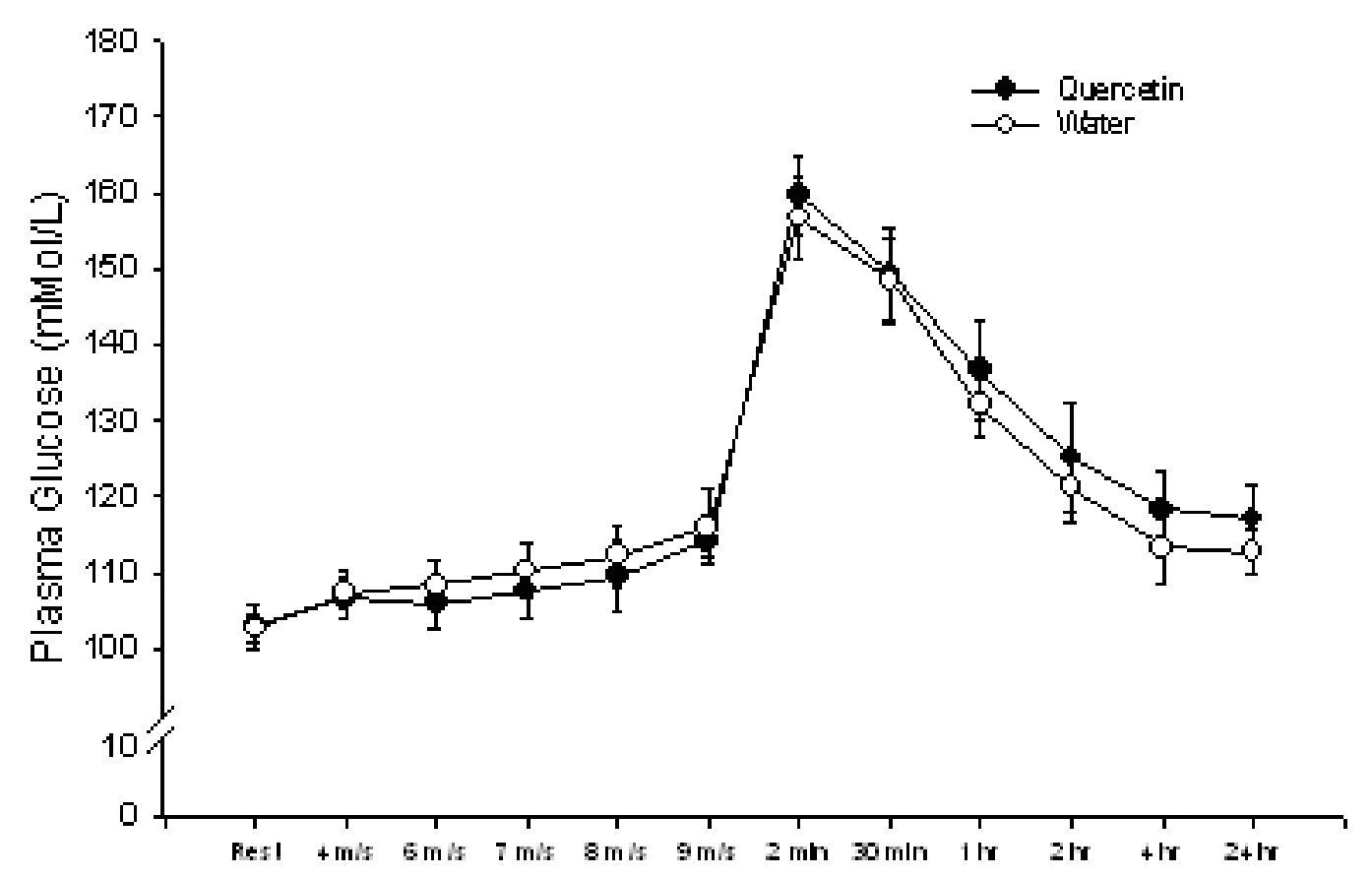

Figure 12: Plasma glucose levels before, during, and following the GXT. There is a significant effect of exercise $(\mathrm{P}>0.1)$, but no effect of treatment $(\mathrm{P}>0.1)$. 


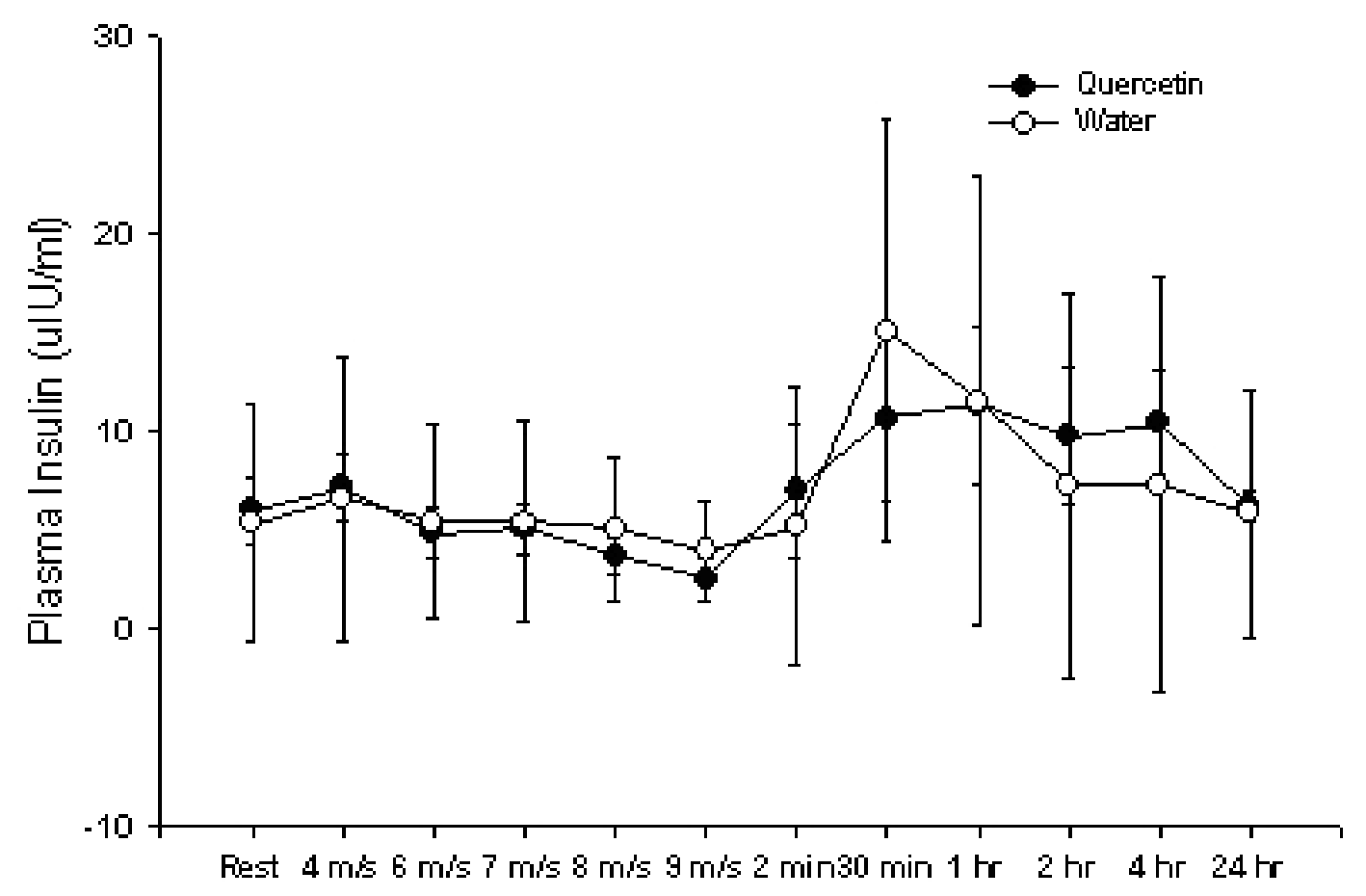

Figure 13: Plasma insulin levels before, during, and following the GXT. There are no significant effects of either exercise or treatment ( $P>0.1$ for both measurements).

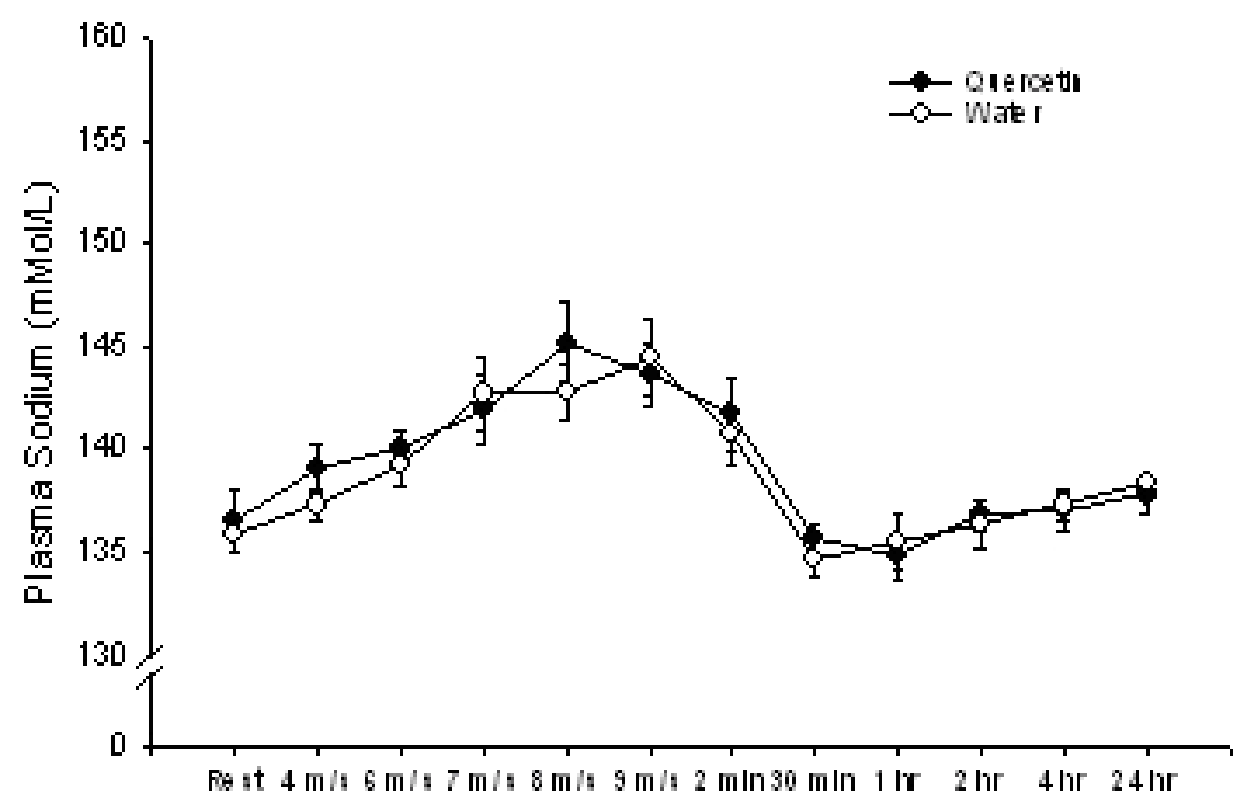

Figure 14: Plasma sodium levels before, during, and following the GXT. There is a significant effect of exercise $(\mathrm{P}<0.1)$, but no effect of treatment $(\mathrm{P}>0.1)$. 


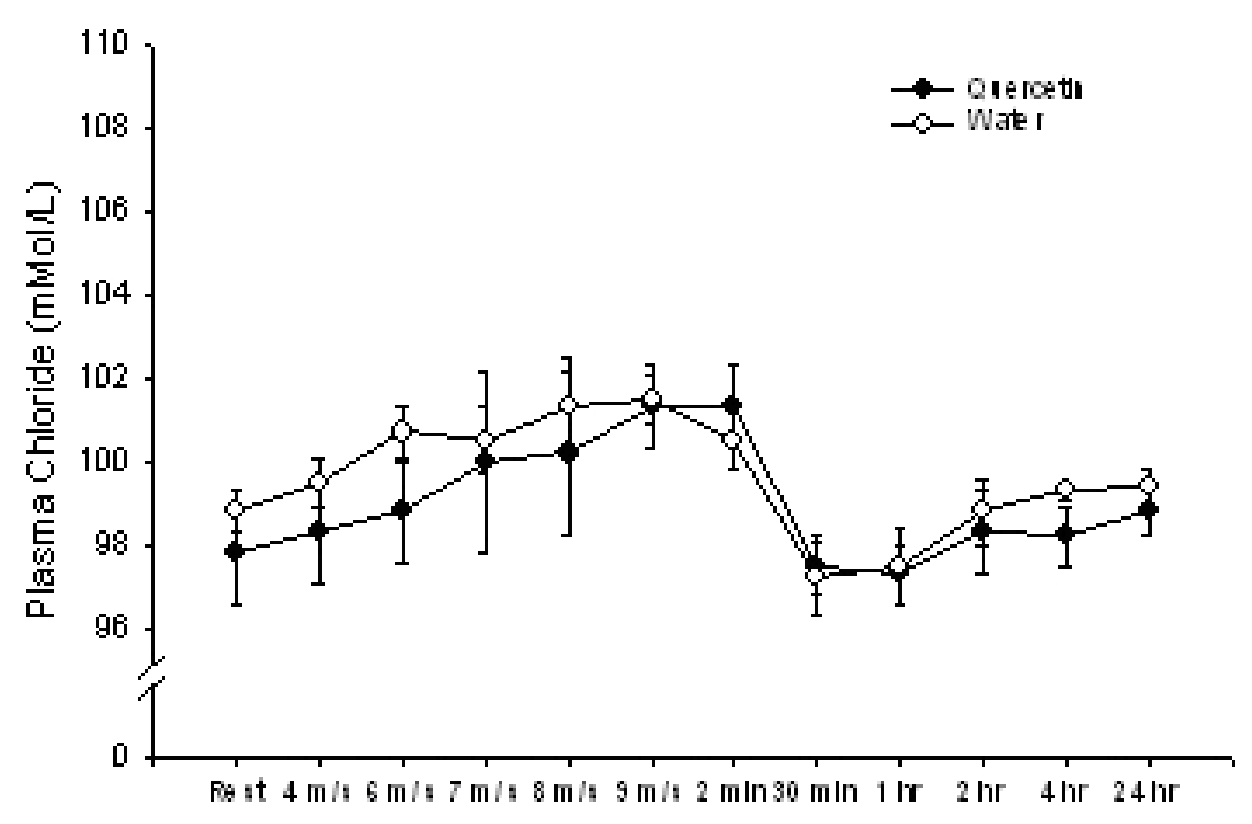

Figure 15: Plasma chloride levels before, during, and following the GXT. There is a significant effect of exercise $(\mathrm{P}<0.1)$, but no effect of treatment $(\mathrm{P}>0.1)$.

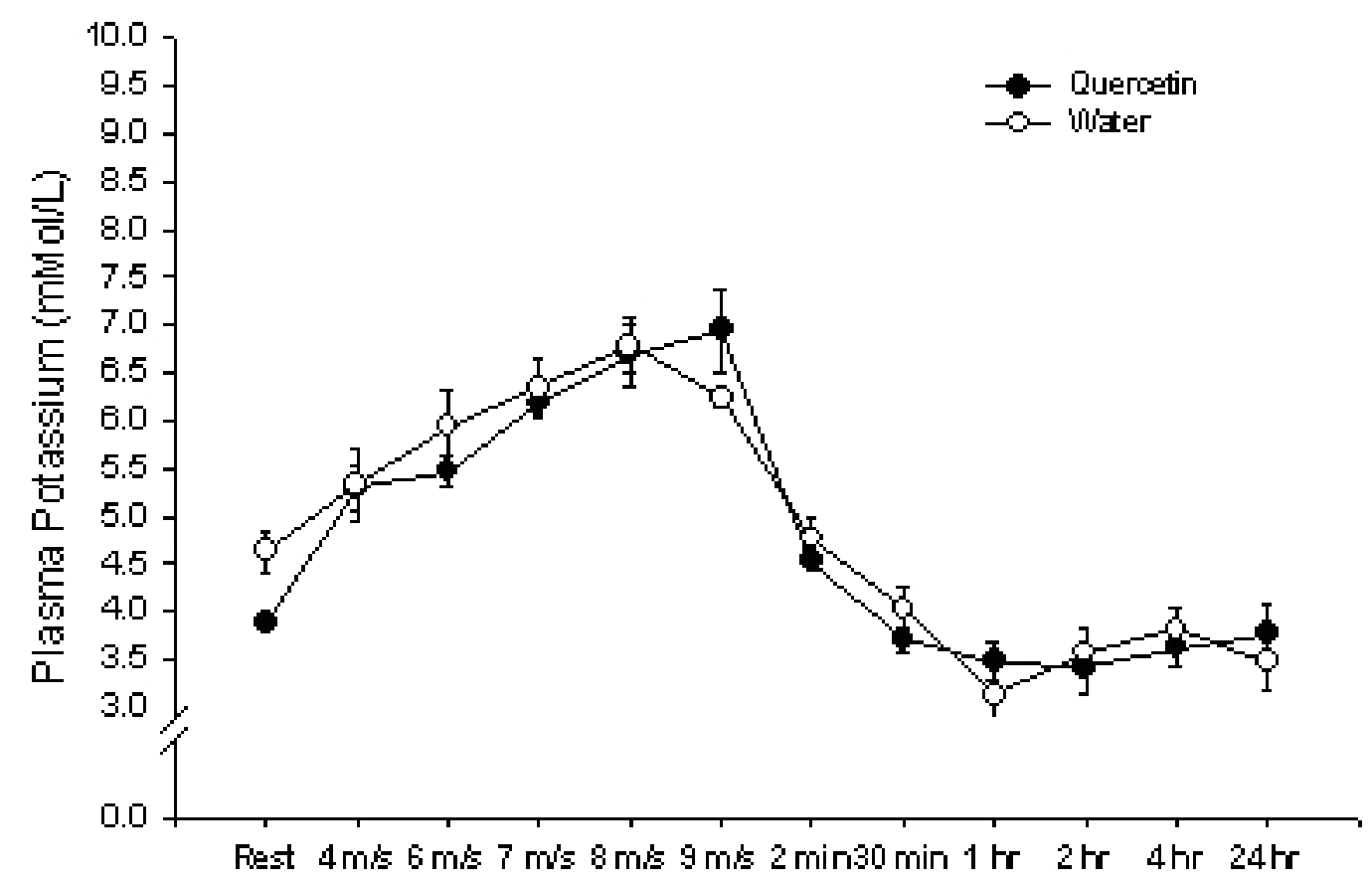

Figure 16: Plasma potassium levels before, during, and following the GXT. There is a significant effect of exercise $(\mathrm{P}<0.1)$, but no effect of treatment $(\mathrm{P}>0.1)$. 


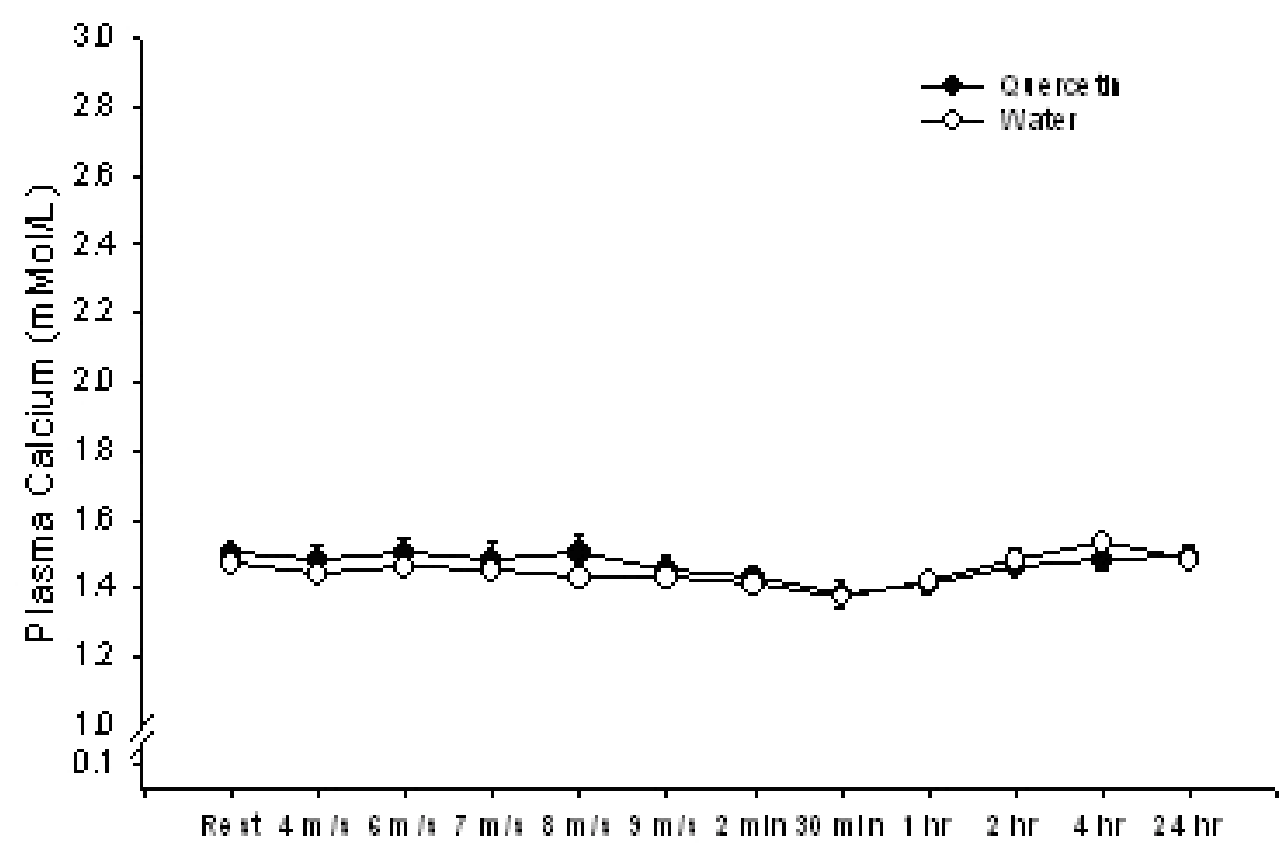

Figure 17: Plasma calcium levels before, during, and following the GXT. There are no significant effects of either exercise or treatment ( $P>0.1$ for both measurements).

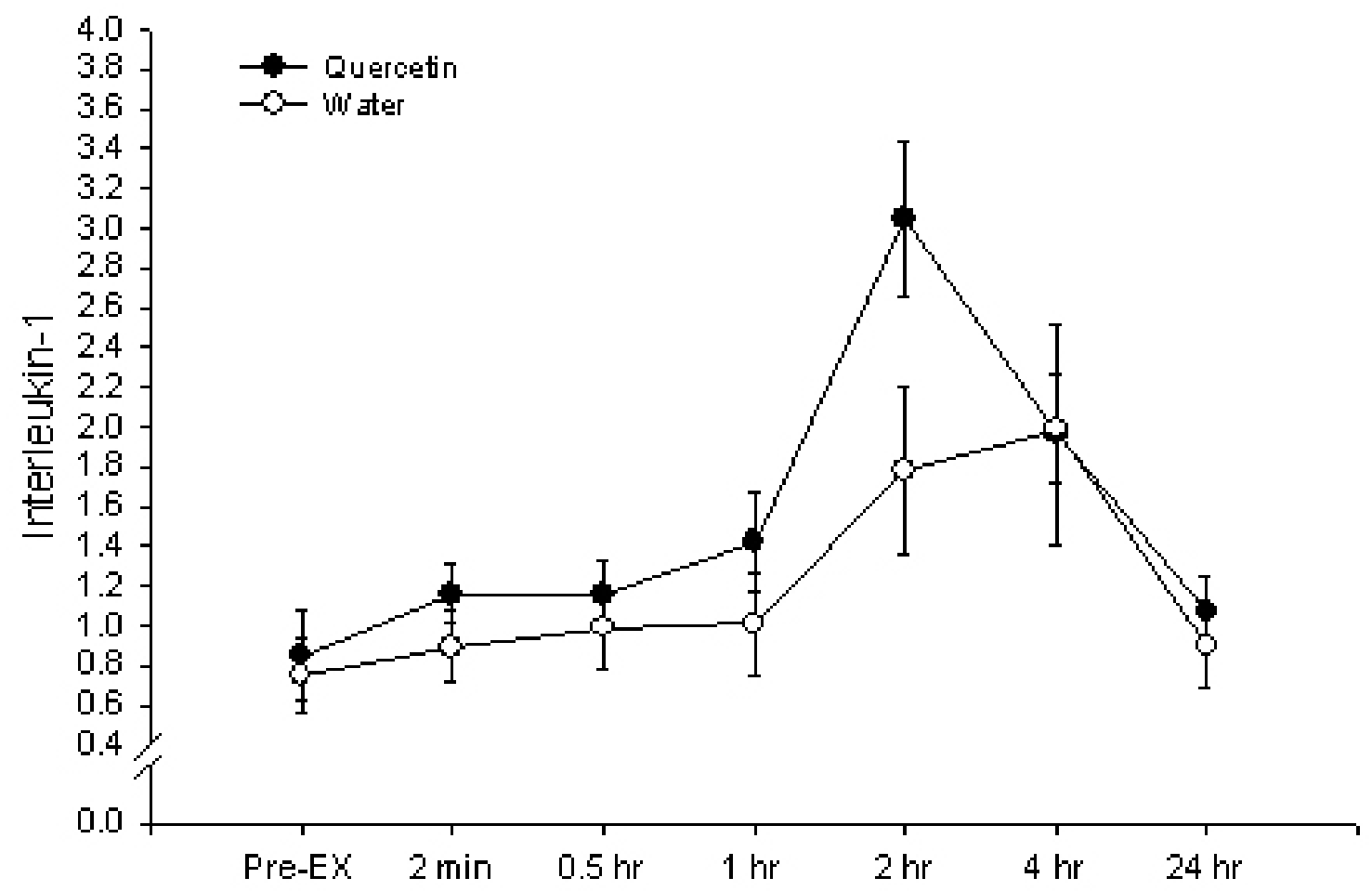

Figure 18: Plasma IL-1 mRNA levels before, during, and following the GXT. There is a significant effect of exercise $(\mathrm{P}<0.1)$, but no effect of treatment $(\mathrm{P}>0.1)$. 


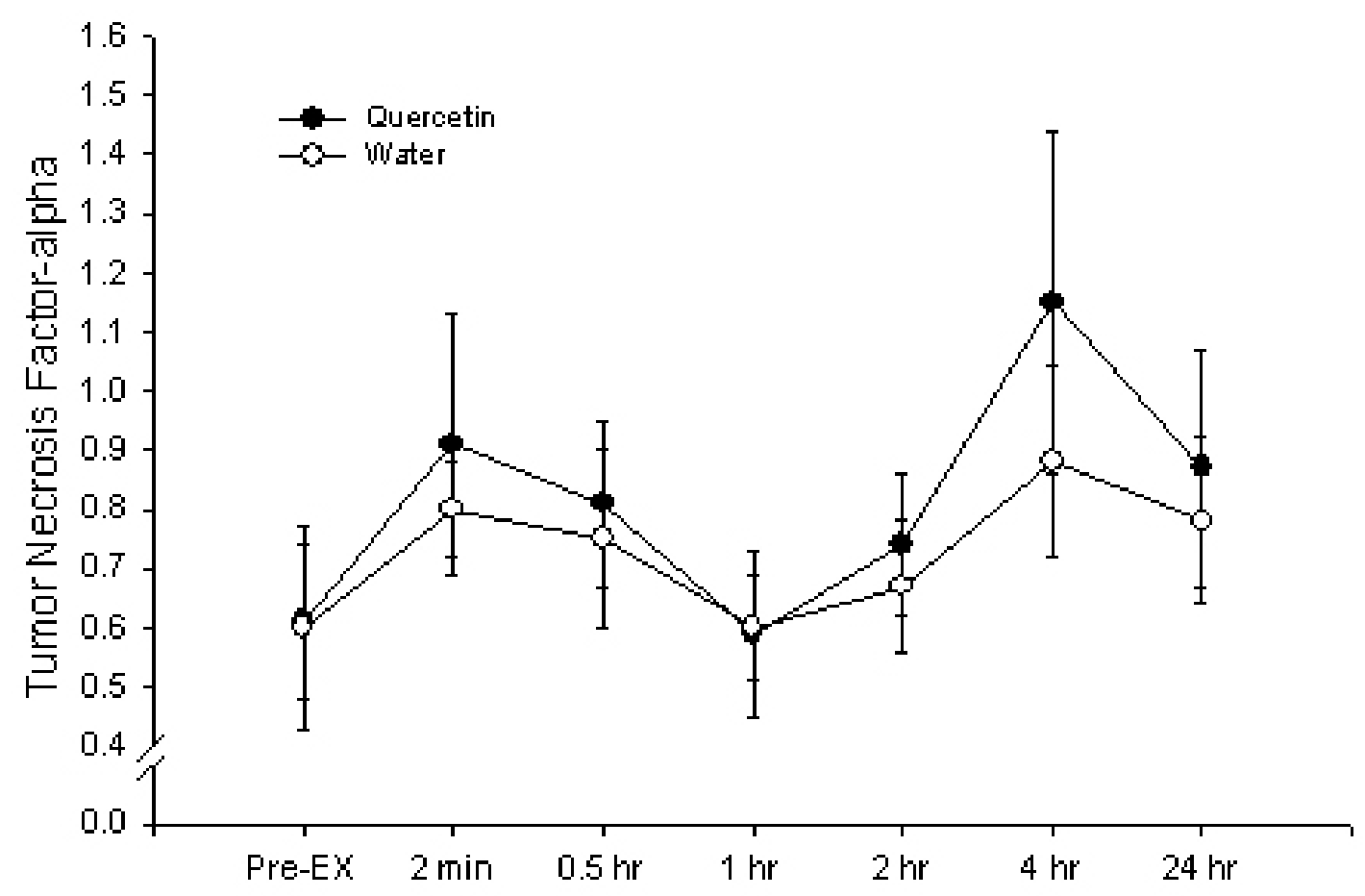

Figure 19: Plasma TNF- $\alpha$ mRNA levels before, during, and following the GXT. There is a significant effect of exercise $(\mathrm{P}<0.1)$, but no effect of treatment $(\mathrm{P}>0.1)$.

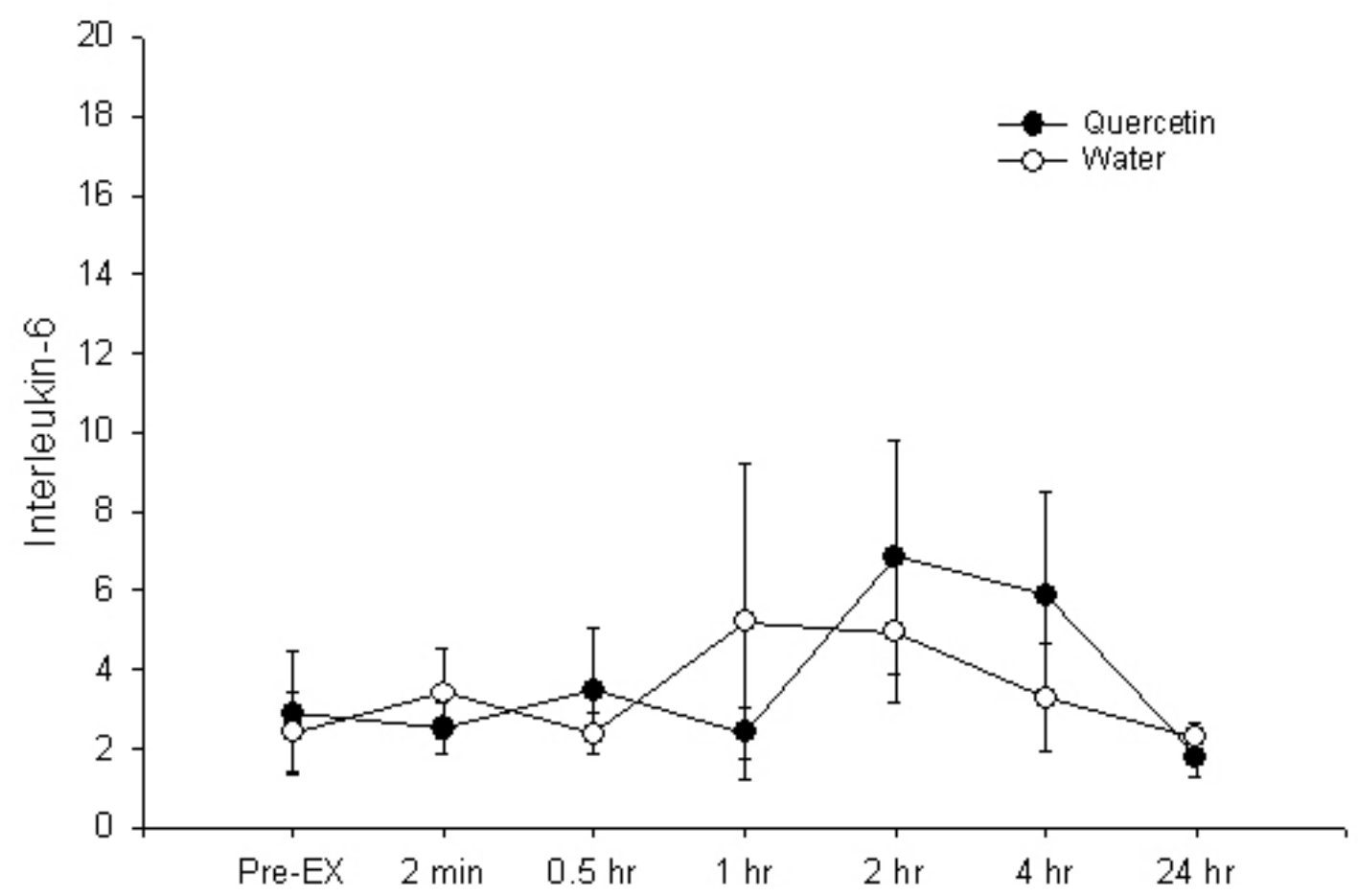

Figure 20: Plasma IL-6 mRNA levels before, during, and following the GXT. There are no significant effects of either exercise or treatment ( $P>0.1$ for both measurements). 


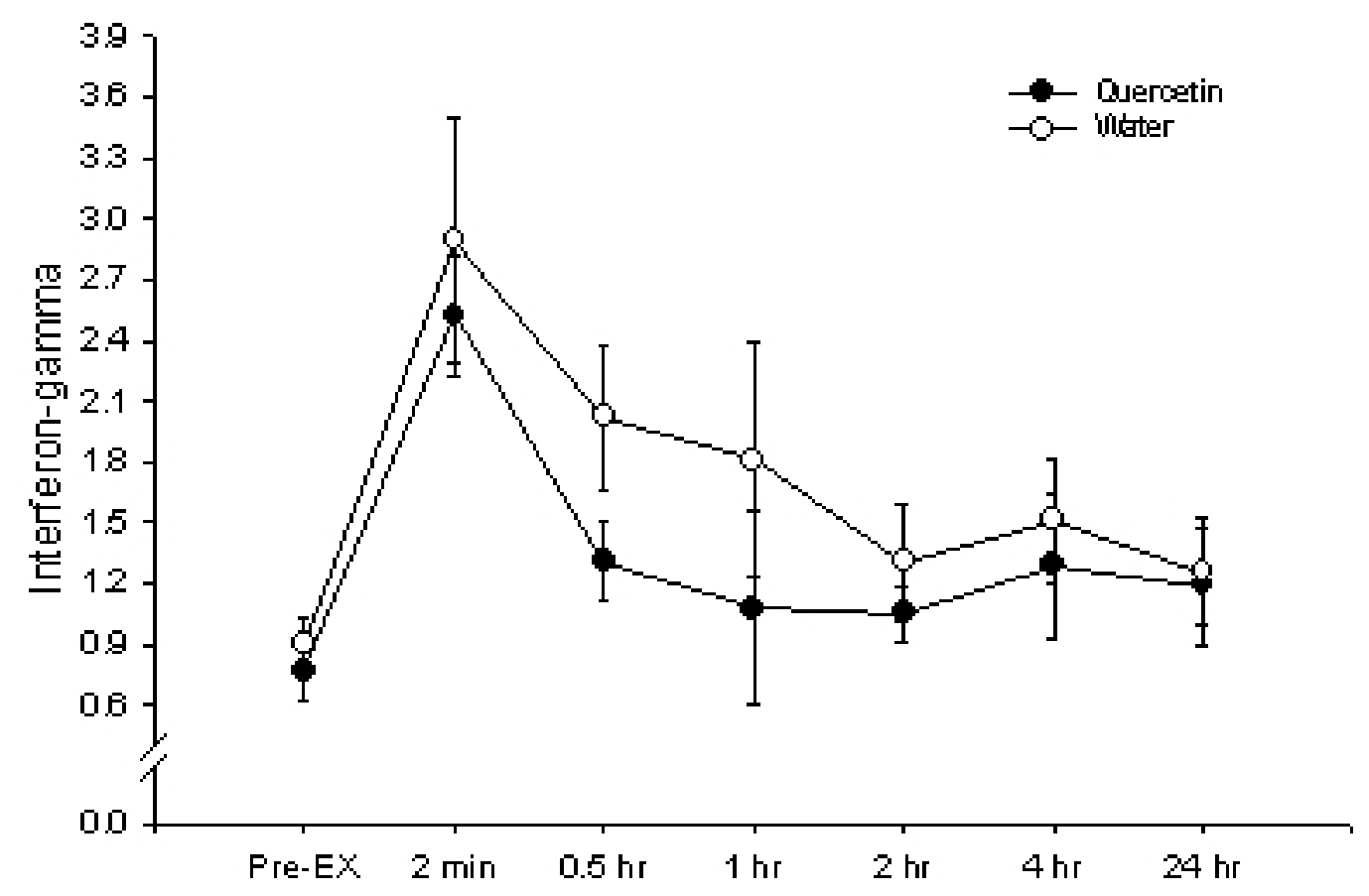

Figure 21: Plasma IFN- $\gamma$ mRNA levels before, during, and following the GXT. There is a significant effect of exercise $(\mathrm{P}<0.1)$, but no effect of treatment $(\mathrm{P}>0.1)$.

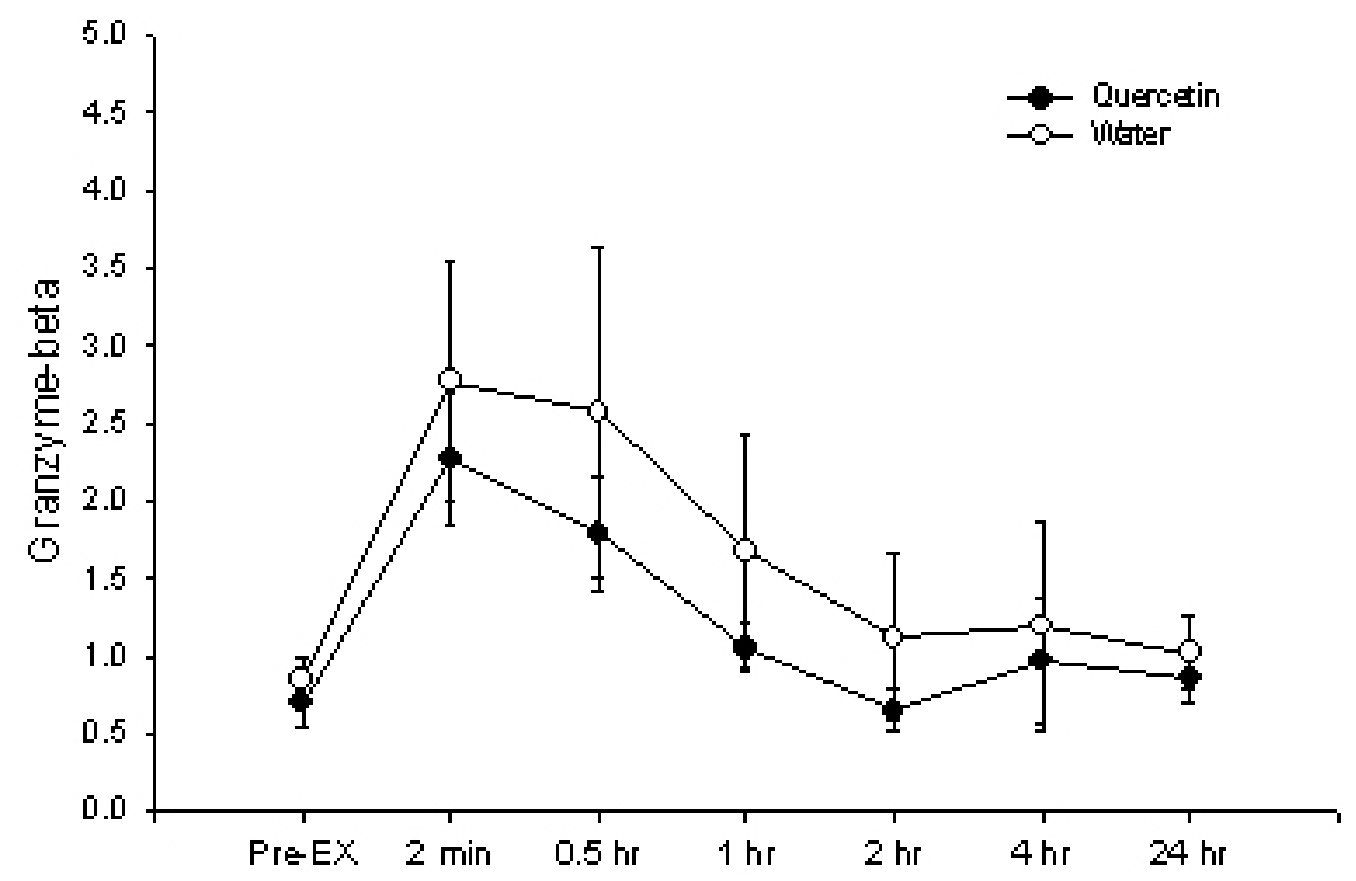

Figure 22: Plasma GrB mRNA levels before, during, and following the GXT. There is a significant effect of exercise $(\mathrm{P}<0.1)$, and a significantly lower level in the quercetin group $(\mathrm{P}<0.1)$. 


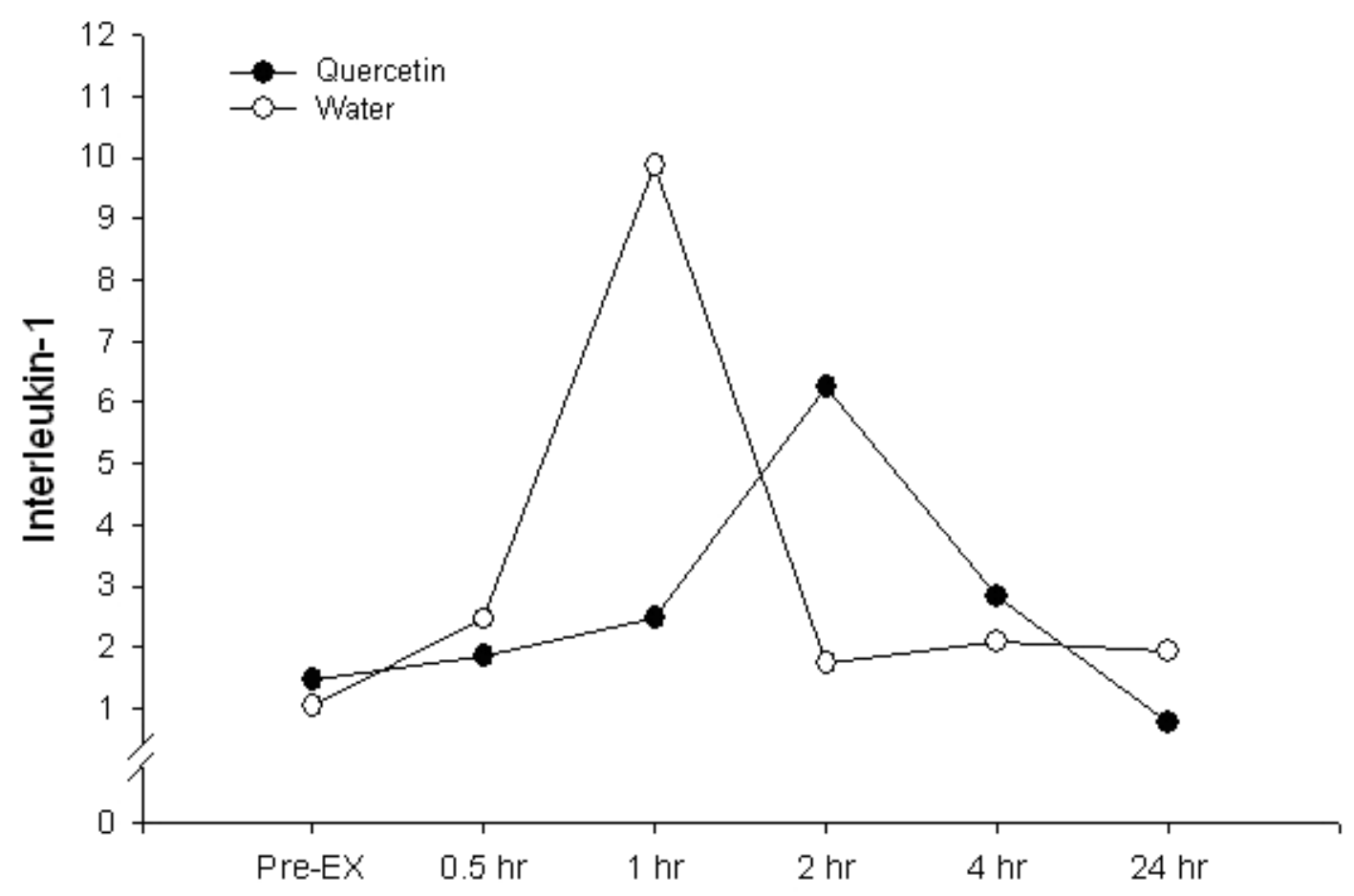

Figure 23: Muscle IL-1 mRNA levels before and after the GXT. There is a significant effect of exercise, $(\mathrm{P}<0.1)$ but no effect of treatment $(\mathrm{P}>0.1)$

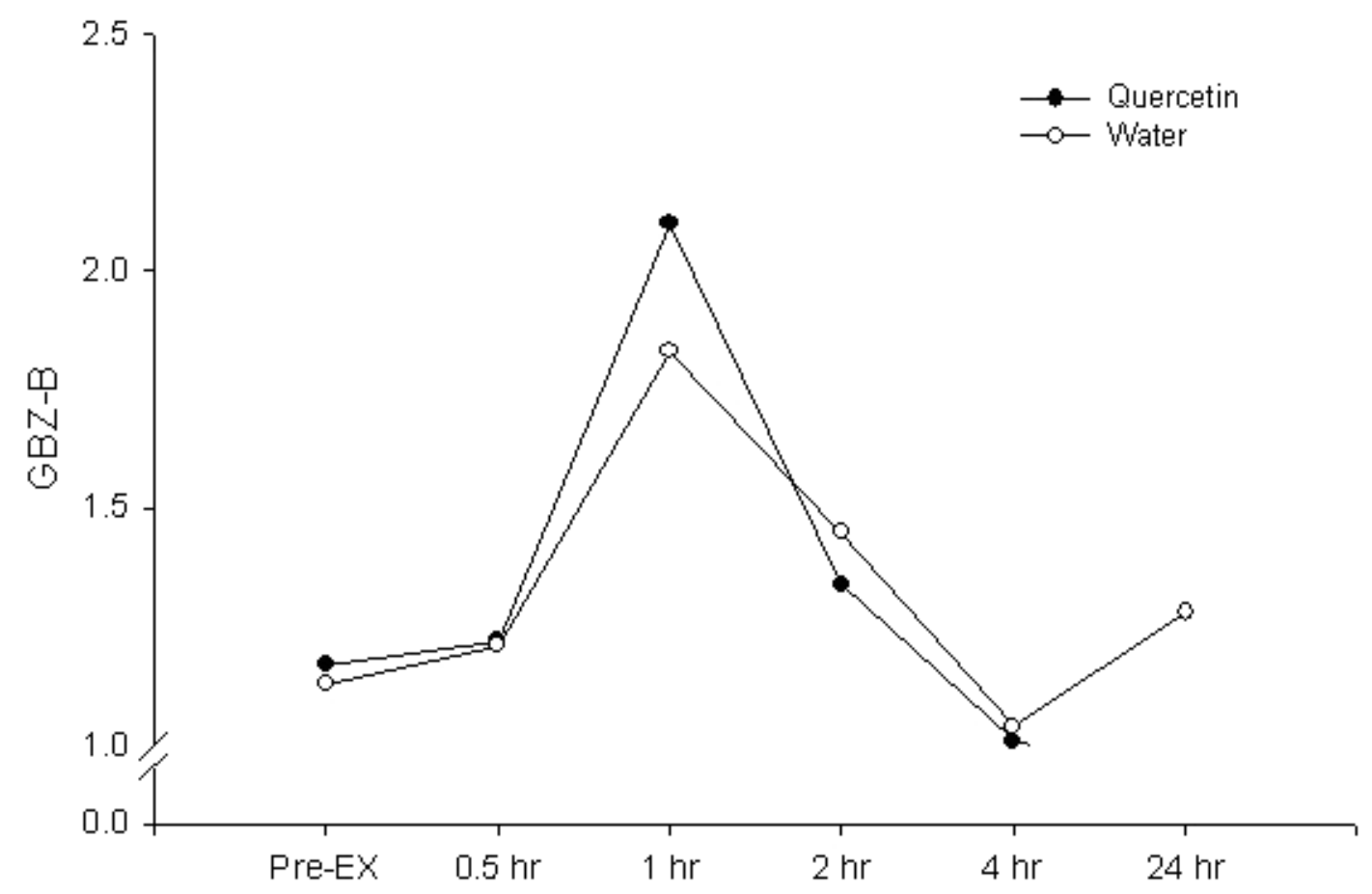

Figure 24: MuscleGrB mRNA levels before and after the GXT. There is a significant effect of exercise, $(\mathrm{P}<0.1)$ but no effect of treatment $(\mathrm{P}>0.1)$. 